\title{
Article \\ Concomitant Antihyperalgesic and Antitumor Effects of Gabapentin in a Murine Cancer Pain Model
}

\author{
Beatriz Elena Brito ${ }^{1}$, María Alejandra García ${ }^{1}{ }^{10}$, Yetsenia María De Gouveia ${ }^{1}$, Pura Bolaños ${ }^{2}$, Sindy Devis ${ }^{3}$, \\ Geraldinee Bernal ${ }^{1}$, Víctor Alejandro Tortorici-Brito ${ }^{1}$, Leslie Baute ${ }^{1}$, Gabriel Díaz-Serrano ${ }^{3}$ (D) \\ and Víctor Tortorici ${ }^{3,4, *}$ \\ 1 Laboratorio de Patología Celular y Molecular, Centro de Medicina Experimental, Instituto Venezolano de \\ Investigaciones Científicas (IVIC), Caracas 1020A, Venezuela; beatrizbrito2005@yahoo.com (B.E.B.); \\ mariaalejandra_gm@yahoo.es (M.A.G.); yetsenia.mdgp@gmail.com (Y.M.D.G.); \\ geraldineebernal@gmail.com (G.B.); tortorici97@gmail.com (V.A.T.-B.); lesliebaute1@yahoo.es (L.B.) \\ 2 Laboratorio de Fisiología Celular, Centro de Biofísica y Bioquímica, Instituto Venezolano de Investigaciones \\ Científicas (IVIC), Caracas 1020A, Venezuela; bolanosp@gmail.com \\ 3 Laboratorio de Neurofisiología, Centro de Biofísica y Bioquímica, Instituto Venezolano de Investigaciones \\ Científicas (IVIC), Caracas 1020A, Venezuela; sindymdr@gmail.com (S.D.); gdiaz0890@gmail.com (G.D.-S.) \\ 4 Laboratorio de Neurociencia, Departamento de Ciencias del Comportamiento, Escuela de Psicología, \\ Universidad Metropolitana (UNIMET), Caracas 1073, Venezuela \\ * Correspondence: vtortorici@unimet.edu.ve; Tel.: +58-(212)-240-3788
}

check for

updates

Citation: Brito, B.E.; García, M.A.; De Gouveia, Y.M.; Bolaños, P.; Devis, S.; Bernal, G.; Tortorici-Brito, V.A.; Baute, L.; Díaz-Serrano, G.; Tortorici, V. Concomitant Antihyperalgesic and Antitumor Effects of Gabapentin in a Murine Cancer Pain Model. Int. J Mol. Sci. 2021, 22, 9671. https:// doi.org/10.3390/ijms22189671

Academic Editor:

Sebastiano Mercadante

Received: 30 June 2021

Accepted: 12 August 2021

Published: 7 September 2021

Publisher's Note: MDPI stays neutra with regard to jurisdictional claims in published maps and institutional affiliations.

Copyright: (c) 2021 by the authors. Licensee MDPI, Basel, Switzerland. This article is an open access article distributed under the terms and conditions of the Creative Commons Attribution (CC BY) license (https:// creativecommons.org/licenses/by/ $4.0 /)$
Abstract: Cancer pain may be the consequence of physical nerve compression by a growing tumor. We employed a murine model to study whether gabapentin was able to regulate tumor growth, in addition to controlling hyperalgesic symptoms. A fluorescent melanoma cell line (B16-BL6/Zs green) was inoculated into the proximity of the sciatic nerve in male C57BL/ 6 mice. The tumor gradually compressed the nerve, causing hypersensitivity. Tumor growth was characterized via in vivo imaging techniques. Every other day, gabapentin $(100 \mathrm{mg} / \mathrm{Kg})$ or saline was IP administered to each animal. In the therapeutic protocol, gabapentin was administered once the tumor had induced increased nociception. In the preventive protocol, gabapentin was administered before the appearance of the positive signs. Additionally, in vitro experiments were performed to determine gabapentin's effects on cell-line proliferation, the secretion of the chemokine CCL2, and calcium influx. In the therapeutically treated animals, baseline responses to noxious stimuli were recovered, and tumors were significantly reduced. Similarly, gabapentin reduced tumor growth during the preventive treatment, but a relapse was noticed when the administration stopped. Gabapentin also inhibited cell proliferation, the secretion of CCL2, and calcium influx. These results suggest that gabapentin might represent a multivalent strategy to control cancer-associated events in painful tumors.

Keywords: cancer pain; gabapentin; Cav $\alpha 2 \delta$ subunit; tumor growth; hyperalgesia; allodynia

\section{Introduction}

Cancer is often a painful disease that affects the quality of life. At least $15-20 \%$ of patients are likely to suffer from pain during the course of the disease, and an even higher proportion of the population becomes affected at its advanced stages [1,2]. Cancer-induced pain involves multiple symptoms such as hyperalgesia, allodynia, spontaneous pain, and numbness, which may be the consequence of physical nerve compression by the growing tumor, or direct infiltration of the nerve [2]; they may also result from tissue acidosis, the release of chemical algogens by the tumor, or the effects of cancer-prescribed therapies (surgery; chemo- or radiotherapy) [2].

Various cancer-induced pain models involving the inoculation of murine tumor cells into the hind paw or the thigh of mice have been developed [3-6]. Inoculation readily induced heat hyperalgesia and mechanical allodynia. These symptoms reached a maximum around two weeks later, at a time when signs of nerve compromise could be identified [3-6]. 
Since the proposal of the World Health Organization's analgesic ladder [7], not only nonsteroidal anti-inflammatory drugs, but also weak or strong opioids have been employed to control cancer pain. Other drugs, such as metamizole (dipyrone), antidepressants, steroids, $N$-methyl-D-aspartate (NMDA) antagonists, and neuromodulators-including gabapentinoids-have also been used [2,3]. These drugs can be administered alone or in combination, and are usually indicated based on the intensity of pain, without consideringunfortunately - the mechanisms involved. On the other hand, cancer pain usually implies a prolonged use of analgesics and complications associated with their repeated administration $[1,8,9]$; thus, the search for a safer and more effective treatment remains a necessity.

Cancer-induced pain is mediated by the increased expression of voltage-gated calcium channels (VGCCs) [10]. Moreover, calcium signaling seems to be involved in cancer development processes, such as unregulated cell growth, resistance to apoptosis, enhanced angiogenesis, and invasion [11-14]. Overexpression of the alpha-2-delta subunit of VGCCs (Cav $\alpha 2 \delta$ ) - an auxiliary subunit that augments the ion conductance, promoted cell proliferation in vitro, and tumorigenesis in vivo-has also been noted $[11,15,16]$. Thus, regulation of VGCCs may represent an important mechanism to control both cancer pain and tumor progression.

On the other hand, gabapentin exerts an antihyperalgesic action through its binding to Cav $\alpha 2 \delta$ of the L-, N- and P/Q-type VGCCs, modulating both presynaptic calcium influx and the subsequent calcium-mediated glutamate release [17], with the merit of causing only minor side effects at clinically effective doses. There are four Cav $\alpha 2 \delta$ subtypes, and gabapentin binds to VGCCs' alpha-2-delta-1 subunit (Cav $\alpha 2 \delta 1)$ with greater affinity compared to VGCCs' alpha-2-delta-2 subunit (Cav $\alpha 282)$ [18-24].

Another molecule of particular importance in cancer development is the chemokine (C-C motif) ligand 2 (CCL2) - a key mediator of interactions between tumor and host cells, and also an essential participant in the development and maintenance of pain $[10,25]$. Treatment of dorsal root ganglion (DRG) neurons in vitro with CCL2 increased the amount of mRNA for Cav $\alpha 2 \delta[10,26,27]$. Cav $\alpha 2 \delta$, in turn, favors an increase in VGCCs' density in the plasma membrane [21], as well as channel conductance. Evidence suggests that CCL2 is released from tumor cells and promotes phenotypic changes in sensory neurons, which might explain how tumor cells drive functional changes in nociceptors to cause hyperalgesia. Previous findings also indicate that injury to peripheral nerves triggers CCL2 release from afferents in the spinal cord's dorsal horn, leading to pronociceptive effects and causing the production of proinflammatory factors [28]. Moreover, expression of CCR2-one of the CCL2 receptors-is increased in murine spinal cord neurons after peripheral nerve injury, and administration of CCR2 antagonists induces proanalgesic effects [29].

In this study, we employed gabapentin to evaluate its antihyperalgesic effect and also its possible antitumor action in a model of cancer-induced pain using male mice. Our findings suggest that in addition to controlling mechanical and thermal hypersensitivity, gabapentin also regulates tumor proliferation, CCL2 secretion, and calcium influx. These results indicate that using gabapentin to modulate pathophysiological calcium signaling in cancer might represent an effective multivalent therapeutic strategy.

\section{Results}

\subsection{Tumor-Nerve Details}

As depicted in Figure 1, after the inoculation of the tumor cell line, a fluorescent tumor grew in places limited to the outside of the epineurium, with the sciatic nerve surrounded by tumor tissue. The nerve was clearly distinguished from the surrounding tumor, without infiltration, degenerative changes, or motor dysfunction. Hence, the observed modifications in mechanical and thermal sensitivity of the hind paws (the sciatic nerve's territory) could be the consequence of nerve injury, promoted by the progressive compression of a tumor that resembled a neurotropic melanoma or a melanotic schwannoma $[3,30]$. 

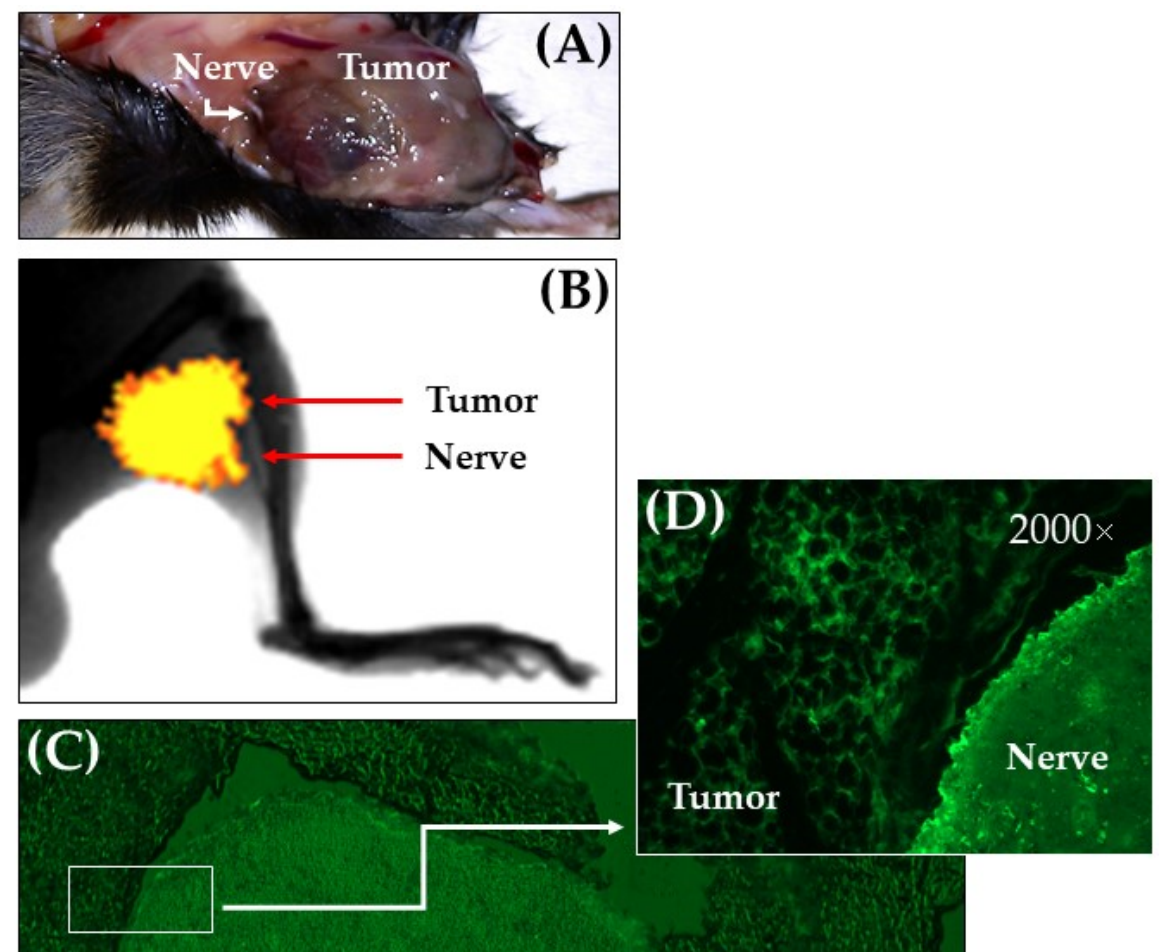

\section{Sciatic}

Nerve

\section{Surrounding \\ Tumor}

$400 \times$

Figure 1. Tumor-nerve details: (A) Tumor mass engulfing the sciatic nerve. (B) In vivo image showing the tumor fluorescence signal co-registered with an anatomical X-ray plane of the inoculated hind paw. (C) Fluorescent microscope image $(400 \times)$ of a transversal section of the sciatic nerve surrounded by the tumor. (D) Insert at higher magnification $(2000 \times)$ showing the fluorescent B16BL6/Zs green cells around the sciatic nerve. Images were taken 17 days after inoculation of the cell line (endpoint).

\subsection{Nociceptive Changes Produced by Tumor Progression}

As shown in Figure 2, the hind paws of the control animals had baseline (BL) values of $3.67 \pm 0.18 \mathrm{~g}$ for the von Frey test $(\mathrm{vF})$ and $5.83 \pm 0.24 \mathrm{~s}$ for the Hargreaves test $(\mathrm{HG})$. Once inoculated with the fluorescent melanoma cell line (B16-BL6/Zs green), and after receiving saline, nociceptive responses gradually increased from day 3 , observing a decrease in the mechanical and thermal withdrawal thresholds that on day 9 reached $1.87 \pm 0.35 \mathrm{~g}$ and $3.57 \pm 0.21 \mathrm{~s}$, respectively. These changes were only observed in the inoculated limbs (saline, paw with tumor day 9 vs. BL, $n=10, p \leq 0.0002,95 \% \mathrm{CI}=-2.627$ to -0.9731 for $\mathrm{vF}$, and $p \leq 0.0001,95 \% \mathrm{CI}=-2.930$ to -1.590 for HG). The response was stable from that moment, reaching $1.66 \pm 0.28 \mathrm{~g}$ and $3.32 \pm 0.24 \mathrm{~s}$ at the end of the experiment (saline, paw with tumor day 17 vs. BL, $n=10 ; p \leq 0.0001$ for both tests, $95 \% \mathrm{CI}=-2.709$ to -1.311 for $\mathrm{vF}$, and $95 \% \mathrm{CI}=-3.223$ to -1.797 for $\mathrm{HG}$ ). 
(A)
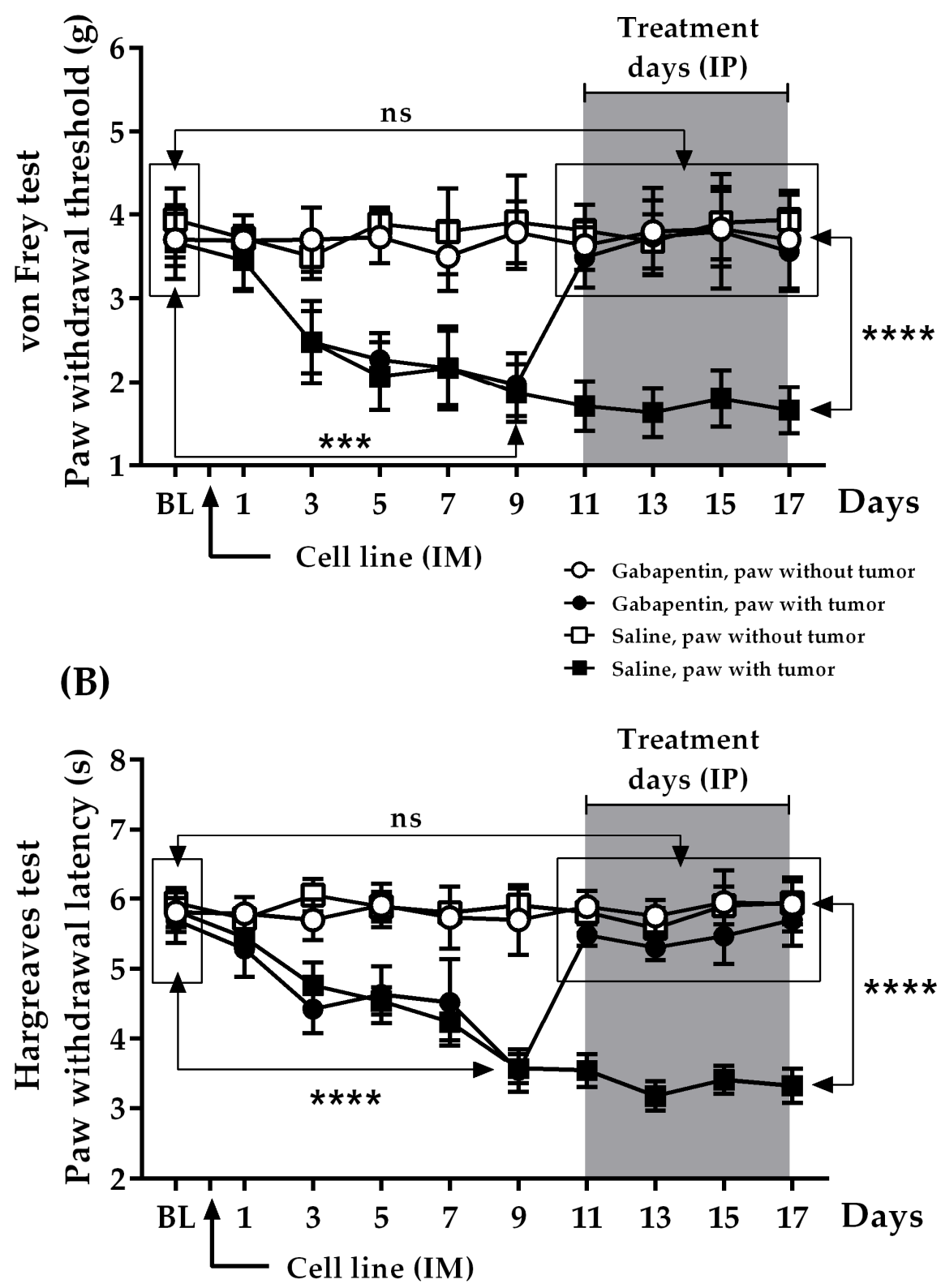

Figure 2. Therapeutic protocol: Gabapentin $(100 \mathrm{mg} / \mathrm{Kg})$ or saline was administered IP (days 11-17, grey box) to evaluate their effects on nociceptive responses caused by tumor progression: (A) von Frey test; (B) Hargreaves test. BL: Baseline (response value before IM inoculation of the cell line and before starting treatment). Contralateral non-inoculated limbs were used as internal controls. ns: non-significant. ${ }^{* * *} p \leq 0.0002,{ }^{* * * *} p \leq 0.0001, n=10$ mice/group. Each point represents the mean \pm SEM of the sample.

\subsection{Effect of Therapeutic Administration of Gabapentin upon Nociceptive Changes Produced by Tumor Progression}

As soon as the therapeutic protocol was started on day 11 (Figure 2), gabapentin returned the behavioral responses of the inoculated limbs to BL levels in the experimental group (gabapentin, paw with tumor day $11 \mathrm{vs.} \mathrm{BL,} n=10,3.49 \pm 0.36 \mathrm{~g}, p=0.7552$, $95 \% \mathrm{CI}=-1.374$ to 1.014 for $\mathrm{vF}$, and $5.48 \pm 0.15 \mathrm{~s}, p=0.5598,95 \% \mathrm{CI}=-0.9525$ to 0.5325 for HG). This effect was maintained throughout the experiment (gabapentin, paw with tumor day $17 \mathrm{vs}$. $\mathrm{BL}, n=10,3.56 \pm 0.47 \mathrm{~g}, p=0.8662,95 \% \mathrm{CI}=-1.463$ to 1.243 for $\mathrm{vF}$, and $5.70 \pm 0.37 \mathrm{~s}, p=0.9839,95 \% \mathrm{CI}=-1.018$ to 1.038 for $\mathrm{HG}$ ). 
Based on these results, gabapentin administration promoted a significant antihypersensitive effect compared to the control group (gabapentin, paw with tumor vs. saline, paw with tumor, day $17, n=10$ /group, $p<0.0001$ for both tests, $3.65 \pm 0.07 \mathrm{~g}$ vs. $1.70 \pm 0.04 \mathrm{~g}$, $95 \% \mathrm{CI}=1.746$ to 2.144 for $\mathrm{vF}$, and $5.49 \pm 0.08 \mathrm{~s}$ vs. $3.36 \pm 0.08 \mathrm{~s}, 95 \% \mathrm{CI}$ for $\mathrm{HG}=1.854$ to 2.406 for HG). Nociceptive responses remained unchanged in control (non-inoculated) hind paws of the animals receiving the drug or saline (gabapentin or saline, paw without tumor, $n=10$ /group).

\subsection{Effect of Preventive Administration of Gabapentin upon Nociceptive Changes Produced by Tumor Progression}

As indicated in Figure 3, the hind paws of the control animals had BL values of $3.74 \pm 0.32 \mathrm{~g}$ for $\mathrm{vF}$ and $5.75 \pm 0.20 \mathrm{~s}$ for HG. In this group, there was, again, a progressive increase in nociception starting from day 3 post-inoculation, as observed with both tests, which tended to stabilize from day 9 (saline, paw with tumor day 9 vs. BL, $n=10$; $1.94 \pm 0.32 \mathrm{~g}, p=0.0009,95 \% \mathrm{CI}=-2.748$ to -0.8462 for $\mathrm{vF}$, and $3.69 \pm 0.19 \mathrm{~s}, p<0.0001$, $95 \% \mathrm{CI}=-2.640$ to -1.480 for $\mathrm{HG}$ ) until the end of treatment (saline, paw with tumor day 17 vs. BL; $n=10,1.89 \pm 0.29 \mathrm{~g}, p=0.0004,95 \% \mathrm{CI}$ for $\mathrm{vF}=-2.757$ to -0.9427 for $\mathrm{vF}$, and $3.14 \pm 0.23 \mathrm{~s}, p<0.0001,95 \% \mathrm{CI}=-3.250$ to -1.970 for $\mathrm{HG}$ ). However, the preventive administration of gabapentin maintained nociceptive responses at BL levels during treatment $(3.53 \pm 0.30 \mathrm{~g}$ and $5.52 \pm 0.31 \mathrm{~s}$, respectively). Interestingly, after ending administration, a delay of around $120 \mathrm{~h}$ was observed in the onset of the positive signs in the inoculated limbs (gabapentin, paw with tumor day $11 \mathrm{vs.} \mathrm{BL,} n=10,3.94 \pm 0.31 \mathrm{~g}$, $p=0.3545,95 \% \mathrm{CI}=-0.4963$ to 1.316 for $\mathrm{vF}$, and $5.29 \pm 0.07 \mathrm{~s}, p=0.4785,95 \% \mathrm{CI}=$ -0.8977 to 0.4377 for HG). This delay might be suggestive of either a residual effect of gabapentin or the existence of a critical time window for the onset of hypersensitivity. In fact, on that day, when comparing gabapentin-treated animals with their control inoculated counterparts, significant differences were observed (gabapentin, paw with tumor vs. saline, paw with tumor, day $11, n=10$ /group, $3.94 \pm 0.31 \mathrm{~g}$ vs. $1.81 \pm 0.35 \mathrm{~g}, p=0.0002$, $95 \% \mathrm{CI}=1.144$ to 3.109 for $\mathrm{vF}$, and $5.29 \pm 0.07 \mathrm{~s}$ vs. $3.80 \pm 0.22 \mathrm{~s}, p<0.0001,95 \% \mathrm{CI}$ $=1.005$ to 1.975 for HG). From day 11, these limbs showed the characteristic increased nociception, so that by day 17 , the responses were not statistically different to those of the control inoculated paws (gabapentin, paw with tumor vs. saline, paw with tumor, day $17, n=10$ /group, $2.58 \pm 0.26 \mathrm{~g}$ vs. $1.89 \pm 0.29 \mathrm{~g}, p=0.0934,95 \% \mathrm{CI}=-0.1283$ to 1.508 for vF, and $3.52 \pm 0.19 \mathrm{~s}$ vs. $3.14 \pm 0.23 \mathrm{~s}, p=0.2190,95 \% \mathrm{CI}=-0.2468$ to 1.007$)$. As expected for an antihyperalgesic agent, nociceptive responses remained unchanged in the non-inoculated paws of animals receiving either gabapentin or saline (gabapentin or saline, paw without tumor, $n=10$ /group). 
(A)
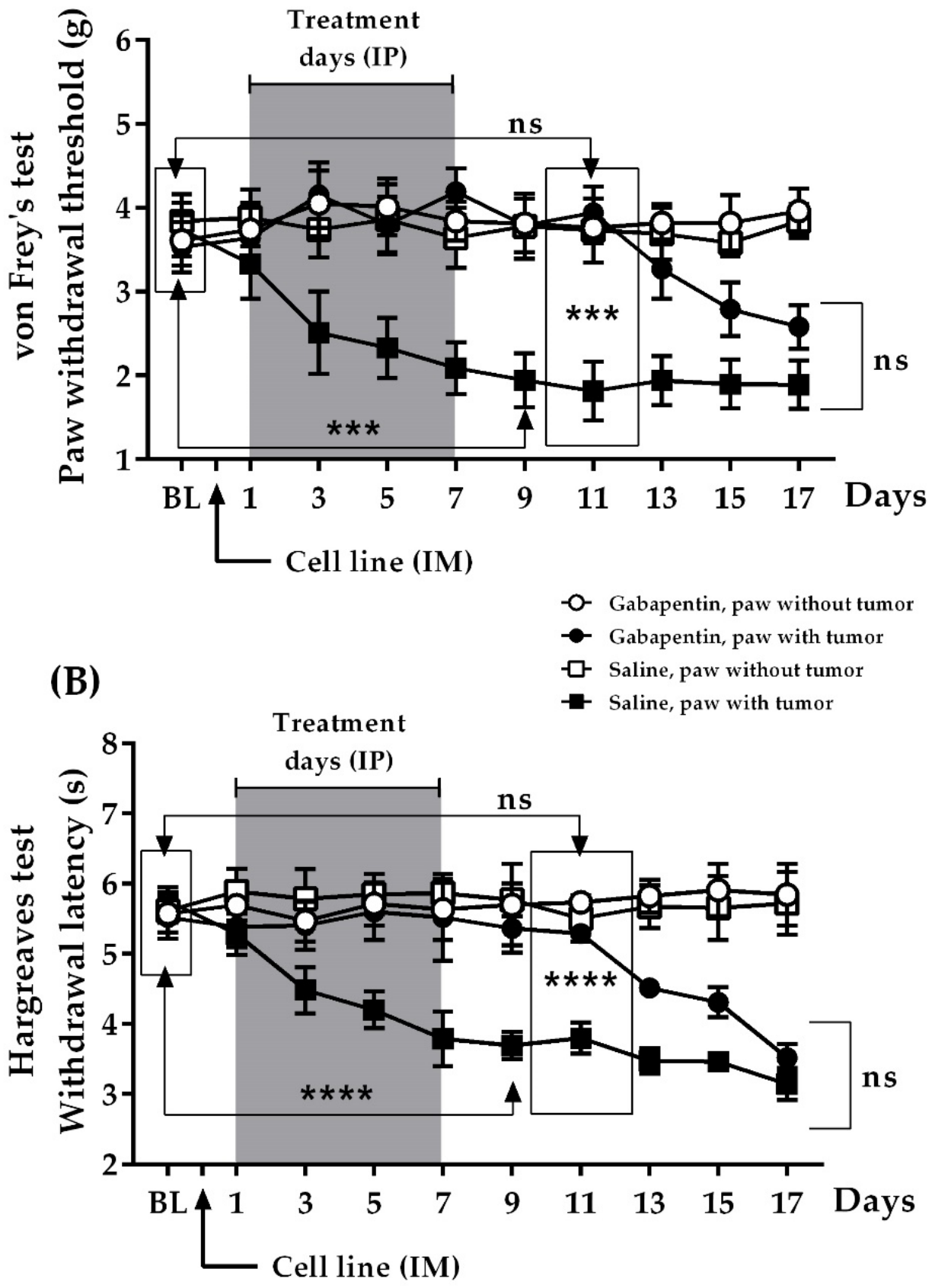

Figure 3. Preventive protocol: Gabapentin (100 mg/Kg) or saline was administered IP (days 1-7, grey box) to evaluate their effects on nociceptive responsiveness caused by tumor progression: (A) von Frey test; (B) Hargreaves test. BL: Baseline (response value before IM inoculation of the cell line and before starting treatment). Contralateral non-inoculated limbs were used as internal controls. ns: non-significant. ${ }^{* * *} p \leq 0.0009,{ }^{* * * *} p<0.0001, n=10$ mice/group. Each point represents the mean \pm SEM of the sample.

\subsection{Effects of Different Treatments on Tumor Growth}

A series of successive in vivo images, taken from the inoculated paws of three representative intact mice, $12 \mathrm{~h}$ after gabapentin administration, are shown in Figure 4 (above). The first row corresponds to an animal that received IP saline. As noted, the tumor was detectable from day 3 until the end of the experiment. Usually, the primary tumor was palpable from day 9 post-inoculation, so that the imaging techniques helped to explain 
behavioral changes even before the tumor was evident. The second row shows an example of how gabapentin prevented tumor growth; the effect was observed beyond the length of the treatment period, possibly indicating a residual effect of the drug or the existence of a critical time for the usual mass enlargement, which also matched the onset of hypersensitivity. However, after day 11, the tumor resumed its growth, reaching a size comparable to that in the control mouse (first row). The therapeutic effect of gabapentin is shown in the third row. As noted, the drug reduced tumor growth during treatment days and, in that mouse, the final size of the tumor was smaller compared to the other animals.

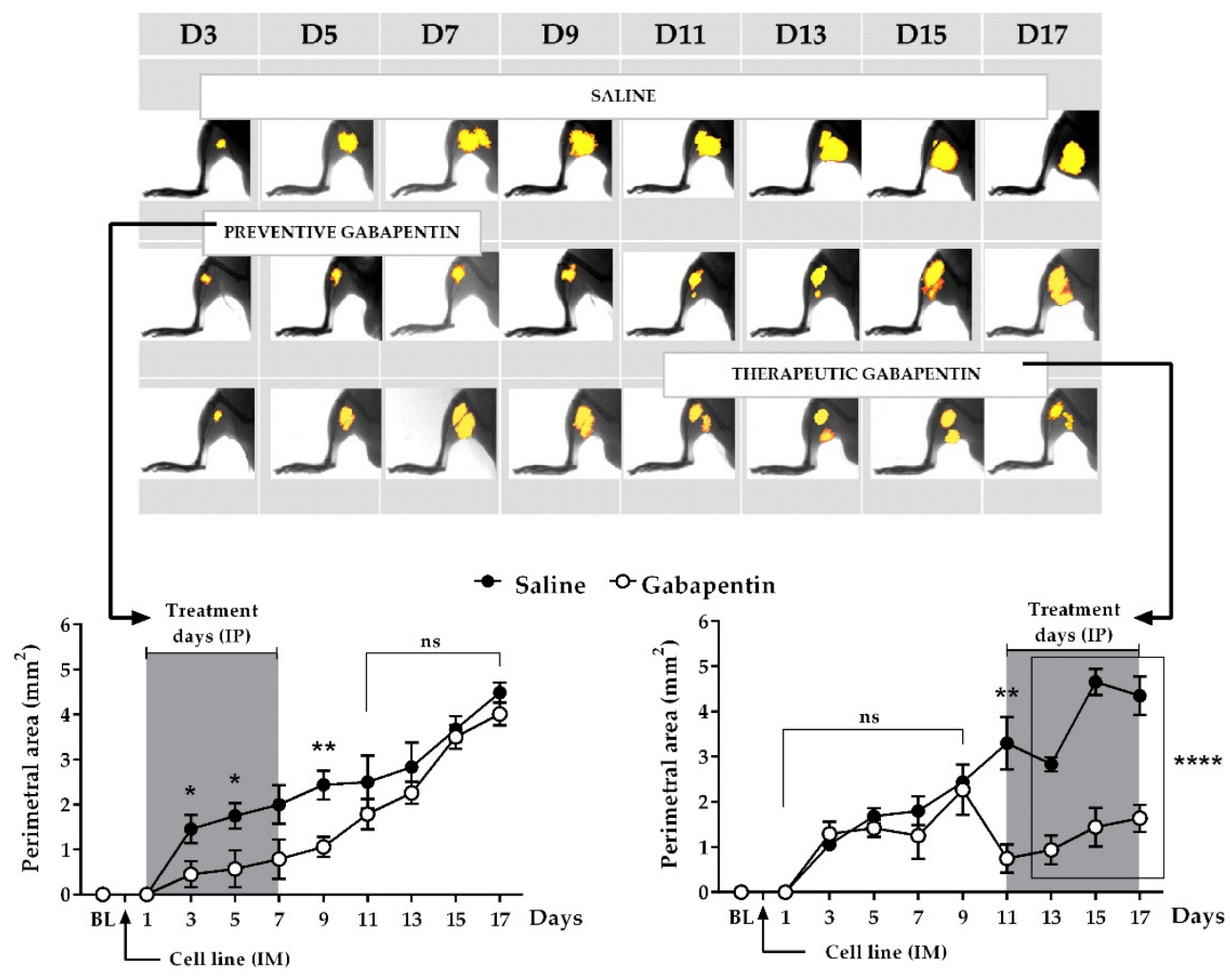

Figure 4. Tumor progression: Above: Representative image sequences, obtained with in vivo imaging techniques, $12 \mathrm{~h}$ after gabapentin administration, indicating tumor progression in three different intact mice receiving either IP saline (first row), preventive IP gabapentin (second row), or therapeutic IP gabapentin (third row) after the inoculation of the cell line. Below: Perimetral area $\left(\mathrm{mm}^{2}\right)$, corresponding to all tumors growing in animals receiving either saline or gabapentin (100 mg/Kg). Left: Preventive treatment. Right: Therapeutic treatment. BL: Baseline (response value before IM inoculation of the cell line and before starting treatment). ns: non-significant. ${ }^{*} p \leq 0.0314,{ }^{* *} p \leq 0.0024,{ }^{* * * *} p \leq 0.0001$, $n=10$ mice/group. Each point represents the mean \pm SEM of the sample.

The perimetral area $\left(\mathrm{mm}^{2}\right)$ of all tumors growing in mice that received either preventive (left) or therapeutic (right) treatment is shown in Figure 4 (below). During the gabapentin preventive treatment, with the exception of day 7 , tumor growth was significantly reduced when compared with saline control animals (saline, paw with tumor vs. gabapentin, paw with tumor; day 3: $1.45 \pm 0.32 \mathrm{~mm}^{2}$ vs. $0.45 \pm 0.29 \mathrm{~mm}^{2}, p=0.0314$, $n=10$ /group, $95 \% \mathrm{CI}=-1.907$ to -0.1004 ; day $5: 1.75 \pm 0.28 \mathrm{~mm}^{2}$ vs. $0.57 \pm 0.41 \mathrm{~mm}^{2}$; $p=0.0285, n=10 /$ group, $95 \% \mathrm{CI}=-2.219$ to -0.1392 ; day $7: 2.00 \pm 0.43 \mathrm{~mm}^{2}$ vs. $0.79 \pm$ $0.44 \mathrm{~mm}^{2}, p=0.0655, n=10$ /group, $95 \% \mathrm{CI}=-2.505$ to 0.08635 ). This effect was observed until day $9\left(2.44 \pm 0.32 \mathrm{~mm}^{2}\right.$ vs. $1.06 \pm 0.22 \mathrm{~mm}^{2}, p=0.0024, n=10 /$ group, $95 \% \mathrm{CI}=-2.194$ to -0.5569 ), two days after finishing drug administration. From that point, the inhibitory effect of gabapentin on tumor growth gradually decreased, and tumors reached a similar size in both groups by the end of the assay. 
When the animals ( $n=10$ /group) received the therapeutic gabapentin treatment, tumor growth was significantly reduced (saline, paw with tumor vs. gabapentin, paw with tumor; day 11: $3.30 \pm 0.59 \mathrm{~mm}^{2}$ vs. $0.75 \pm 0.31 \mathrm{~mm}^{2}, p=0.0012,95 \% \mathrm{CI}=-3.943$ to -1.156 ; day 13: $2.83 \pm 0.15 \mathrm{~mm}^{2}$ vs. $0.94 \pm 0.32 \mathrm{~mm}^{2}, p<0.0001,95 \% \mathrm{CI}=-2.641$ to -1.147 ; day 15 : $4.65 \pm 0.29 \mathrm{~mm}^{2}$ vs. $1.44 \pm 0.43 \mathrm{~mm}^{2}, p<0.0001,95 \% \mathrm{CI}=-4.299$ to -2.119 ; day 17: 4.35 \pm 0.42 vs. $1.64 \pm 0.30 \mathrm{~mm}^{2}, p<0.0001,95 \% \mathrm{CI}=-3.800$ to -1.621 ). Surprisingly, this effect was observed $12 \mathrm{~h}$ after the first therapeutic administration, and remained for the duration of the administration period, rendering a smaller tumor size by the end of the experiment.

\subsection{In Vitro Proliferation Assays}

Our results indicate (Figure $5 \mathrm{~A}$ ) that gabapentin was able to significantly reduce the proliferation of the melanoma cell line B16-BL6/Zs green in a dose-dependent manner. After $96 \mathrm{~h}$ of incubation with the drug, and compared to culture media without gabapentin (Figure $5 \mathrm{~B})$, the most inhibitory effective doses were $1000 \mu \mathrm{g} / \mathrm{mL}(35.78 \pm 0.61 \%$ of proliferation, $n=6, p<0.0001,95 \% \mathrm{CI}=-65.58$ to -62.86$)$ and $2000 \mu \mathrm{g} / \mathrm{mL}(18.12 \pm 0.72 \%$ of proliferation; $n=6 ; p<0.0001,95 \% \mathrm{CI}=-83.48$ to -80.28 ). These results, obtained from MTT assays, suggest that instead of cytotoxicity, gabapentin seems to promote a cytostatic effect. Under these conditions, cell adhesion to the culture plate was maintained, and no dead cells were observed under the microscope. Interestingly, a significant relapse of cell proliferation was observed in the culture wells $72 \mathrm{~h}$ after washing gabapentin out of the plates, even for those that previously received the highest inhibitory doses $(192.40 \pm 5.54 \%$, $n=5 ; p=0.0046,95 \% \mathrm{CI}=-34.38$ to -8.818 for the cells that were under $1000 \mu \mathrm{g} / \mathrm{mL}$, and $143.00 \pm 6.14 \%, n=5 ; p<0.0001,95 \% \mathrm{CI}=-85.15$ to -56.85 for the cells that were under $2000 \mu \mathrm{g} / \mathrm{mL}$ ). These findings support our previous in vivo observations using both protocols of gabapentin administration, and also during treatment suspension.

(A)

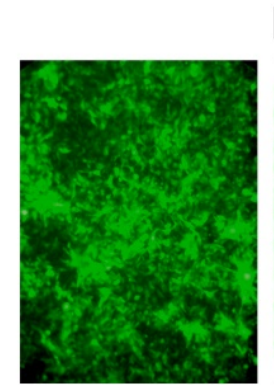

W/O

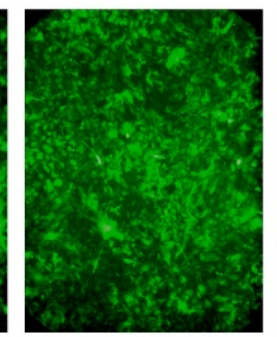

10

$96 \mathrm{~h}$ gabapentin $(\mu \mathrm{g} / \mathrm{mL})$

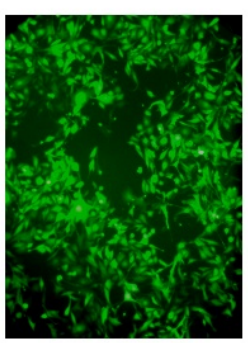

100

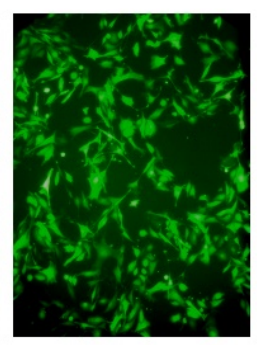

1000

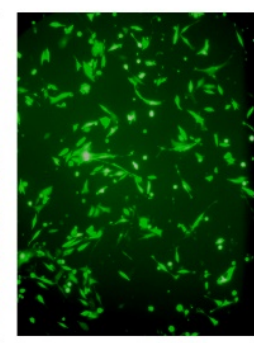

2000

Figure 5. Cont. 
(B)

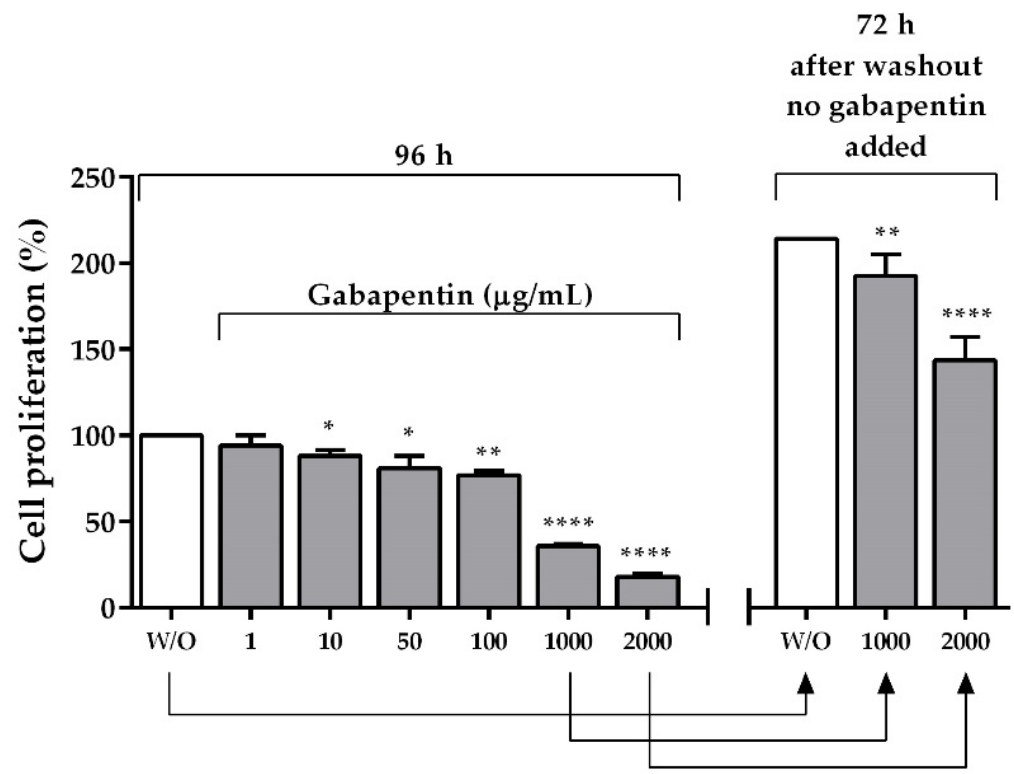

Figure 5. Cell proliferation: (A) Representative inverted fluorescent microscope images $(200 \times)$ of the melanoma cell line B16-BL6/Zs green incubated for $96 \mathrm{~h}$ under different gabapentin doses (10, 100, 1000, or $2000 \mu \mathrm{g} / \mathrm{mL}$ ). (B) Proliferation assay using MTT to verify viability. The results are expressed as a percentage of cellular proliferation after $96 \mathrm{~h}$ of incubation with different doses of gabapentin $(1,10,50,100,1000$, or $2000 \mu \mathrm{g} / \mathrm{mL})$ compared with non-treated cells (100\% proliferation), and after $72 \mathrm{~h}$ of gabapentin washout (no additional gabapentin added). Each column represents the mean \pm SEM of the sample. ${ }^{*} p \leq 0.05,{ }^{* *} p=0.0046,{ }^{* * * *} p<0.0001$.

\subsection{Chemokine CCL2 Determination}

In supernatants obtained from our previous proliferation assays, CCL2 concentration was determined (Figure 6). Our findings indicate that B16-BL6/Zs green murine melanoma cells spontaneously secrete the chemokine CCL2 into the culture media (supernatants from cultures without gabapentin), contrary to that reported for B16-F10 - another variant cell line of B16 murine melanoma that does not release CCL2 $(59.44 \pm 10.11 \mathrm{pg} / \mathrm{mL}$ at $24 \mathrm{~h}, 255.00 \pm 29.41 \mathrm{pg} / \mathrm{mL}$ at $96 \mathrm{~h}$, and $588.03 \pm 85.20$ at $72 \mathrm{~h}$ after washout) [31,32]. When B16-BL6/Zs green cells were incubated during $96 \mathrm{~h}$ with the most effective doses of gabapentin (1000 or $2000 \mu \mathrm{g} / \mathrm{mL})$, a dose-dependent inhibition of CCL2 secretion was observed $(182.00 \pm 9.05 \mathrm{pg} / \mathrm{mL}, n=3, p=0.0766,95 \% \mathrm{CI}=-158.4$ to 12.43 for $1000 \mu \mathrm{g} / \mathrm{mL}$, and $90.00 \pm 0.66 \mathrm{pg} / \mathrm{mL}, n=3, p \leq 0.005,95 \% \mathrm{CI}=-246.7$ to -83.32 for $2000 \mu \mathrm{g} / \mathrm{mL}$ vs. control supernatants without gabapentin). It should be noted that $72 \mathrm{~h}$ after removing gabapentin from the wells a significant residual effect of the previous incubation with the drug was still present $(332.18 \pm 13.68 \mathrm{pg} / \mathrm{mL}, p \leq 0.04, n=3,95 \% \mathrm{CI}=-495.4$ to -16.27 for $1000 \mu \mathrm{g} / \mathrm{mL}$, and $245.00 \pm 14.52 \mathrm{pg} / \mathrm{mL}, p=0.0166, n=3,95 \% \mathrm{CI}=-583.0$ to -103.0 for $2000 \mu \mathrm{g} / \mathrm{mL}$ vs. control without gabapentin), which resembled our in vivo observations. 


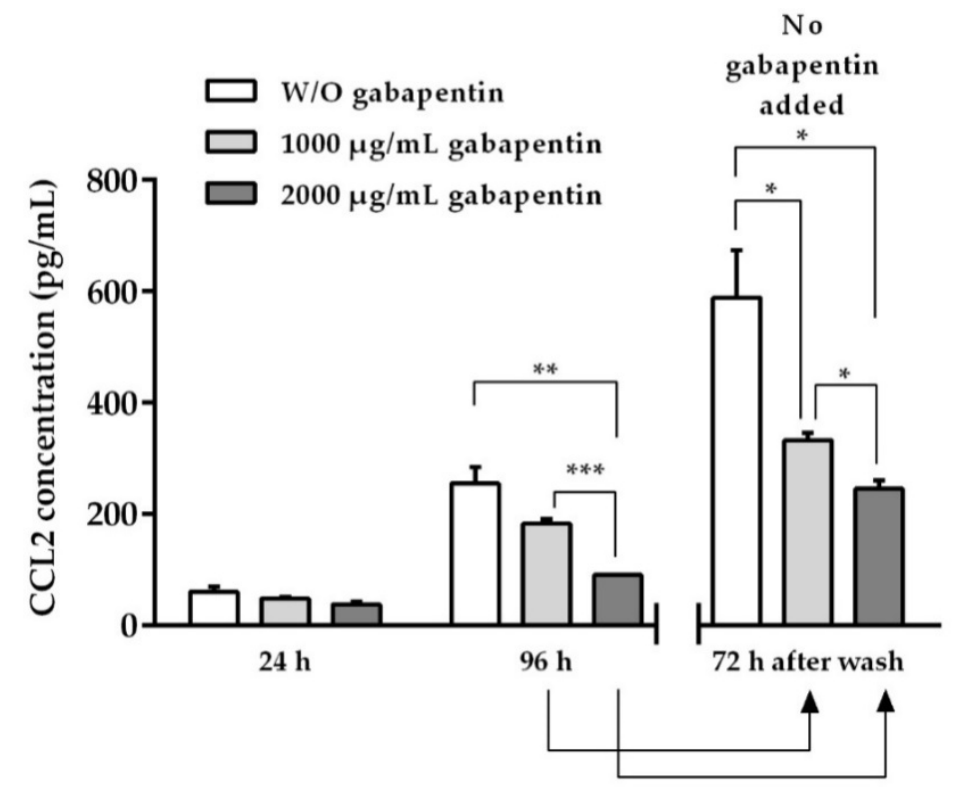

Figure 6. CCL2 concentration: Effect of gabapentin on the CCL2 secretion in B16-BL6/Zs green murine melanoma cells. Cultures were incubated with gabapentin $(1000$ or $2000 \mu \mathrm{g} / \mathrm{mL})$ for 24 and $96 \mathrm{~h}$, and $72 \mathrm{~h}$ after gabapentin washout (no additional gabapentin added). ELISA analyzed supernatants obtained from 3 independent assays ( $n=3$, each by triplicate), which were used to determine the chemokine concentration. Each column represents the mean \pm SEM. ${ }^{*} p \leq 0.04$, ** $p \leq 0.005,{ }^{* * *} p \leq 0.0005$.

\subsection{Calcium Influx in B16-BL6 Melanoma Cells}

Calcium influx was determined in murine B16-BL6 melanoma cells incubated for $24 \mathrm{~h}$ with gabapentin (1000 or $2000 \mu \mathrm{g} / \mathrm{mL}$ ). Then, cells were loaded with Fura-2/AM, the high-affinity calcium-selective fluorescent indicator. Representative records from single melanoma cells showing the time course of the fluorescence ratio signal $(340 / 380 \mathrm{~nm})$ are shown in Figure 7A. After the initial observation of the baseline calcium influx (using a standard solution containing $1 \mathrm{mM} \mathrm{CaCl} 2$ ), a depolarizing condition was promoted by adding $130 \mathrm{mM} \mathrm{KCl}$ to the perfusion chamber. This mediated depolarization induced barely detectable changes in the cytosolic calcium levels in melanoma cells incubated with both doses of gabapentin (even though it was slightly higher in cells incubated with $1000 \mu \mathrm{g} / \mathrm{mL}$ ). According to these results, gabapentin, through its binding to Cav $\alpha 2 \delta$ of VGCCs, could modulate calcium influx in melanoma cells. However, in the control cell without gabapentin, high $\mathrm{KCl}$-mediated depolarization triggered a marked increase in the fluorescence ratio. Later, after recovering baseline levels, the addition of calcium to the bath $(10 \mathrm{mM} \mathrm{CaCl} 2)$ caused a calcium influx response in all conditions, suggesting that cells treated with gabapentin were metabolically active, with the dose of $2000 \mu \mathrm{g} / \mathrm{mL}$ being the one that caused the greatest inhibition of calcium entry. Since gabapentin should affect the entry of ionized calcium through most VGCCs, this influx must involve different mechanisms. 
(A)

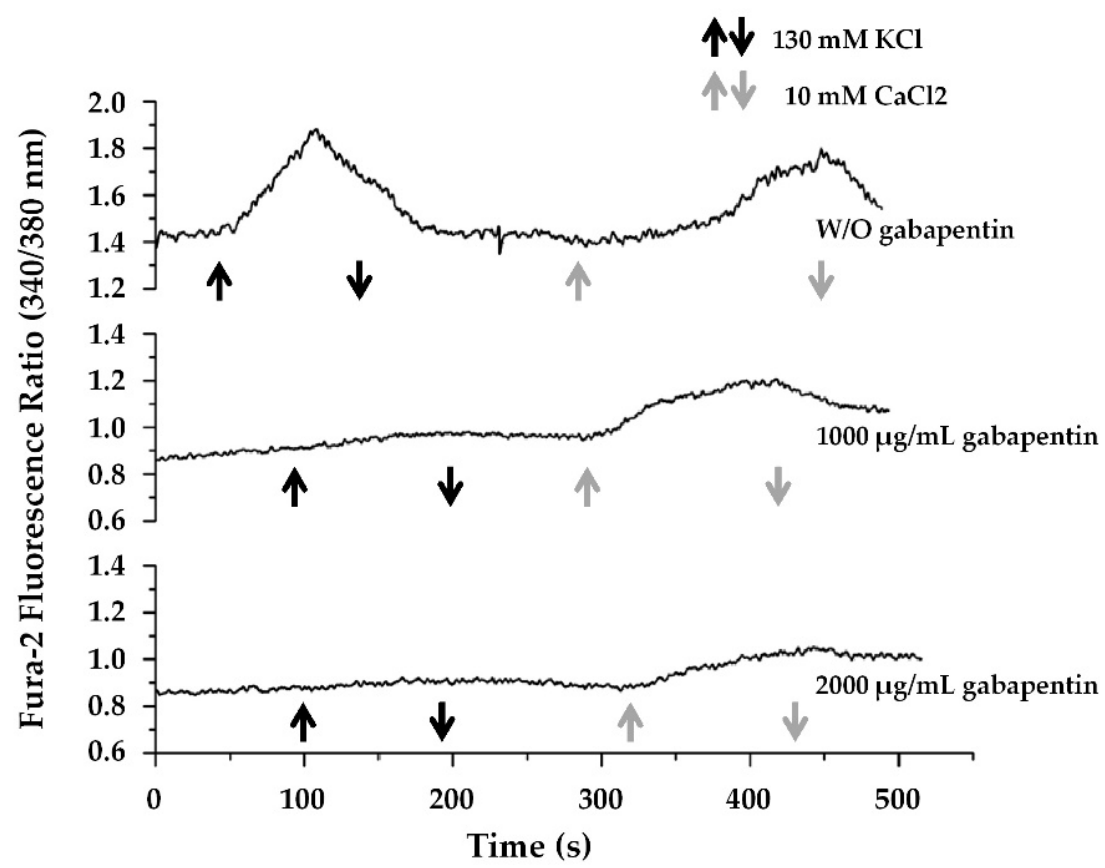

(B)

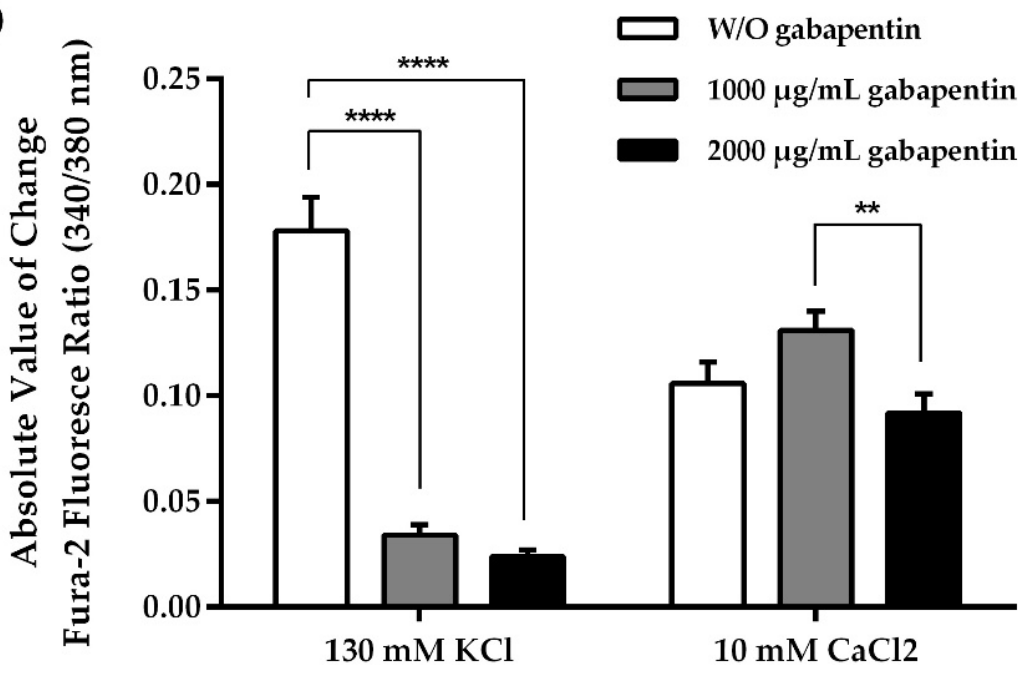

Figure 7. Calcium influx: Effect of gabapentin treatment on calcium influx in B16-BL6 murine melanoma cells: (A) Representative records showing changes in the time course of Fura-2 fluorescence ratio $(340 / 380 \mathrm{~nm})$ induced by $130 \mathrm{mM} \mathrm{KCl}$ or $10 \mathrm{mM} \mathrm{CaCl}_{2}$, in control and gabapentin-treated cells (1000 or $2000 \mu \mathrm{g} / \mathrm{mL}$ ). Cells were preincubated with gabapentin for $24 \mathrm{~h}$ before starting the experimental procedure, and maintained throughout the recordings. When exposing the cells to $130 \mathrm{mM} \mathrm{KCl}$ (black $\uparrow \downarrow$ ), gabapentin caused calcium influx inhibition. Once the basal calcium level was recovered in the control condition $\left(1 \mathrm{mM} \mathrm{CaCl}_{2}\right)$, the subsequent exposure to $10 \mathrm{mM} \mathrm{CaCl}_{2}$ (grey $\uparrow \downarrow$ ) induced an increase in calcium levels in all conditions. (B) Summarized data showing the absolute value of change (experimental condition baseline) of transient calcium responses after $130 \mathrm{mM} \mathrm{KCl}$ or $10 \mathrm{mM} \mathrm{CaCl}_{2}$ exposure in control and gabapentin-treated cells, expressed as Fura-2 fluorescence ratio $(340 / 380 \mathrm{~nm})$. Bars represent the mean \pm SEM of data from control cells $(n=32)$ and gabapentin-treated cells $(n=17$ under $1000 \mu \mathrm{g} / \mathrm{mL}$, and $n=28$ under $2000 \mu \mathrm{g} / \mathrm{mL}) .{ }^{* *} p=0.0061$; **** $p<0.0001$ vs. control.

As indicated from these representative traces, the starting point of the baseline in all of the gabapentin-treated cells showed lower fluorescence ratios $(0.898 \pm 0.012$ for $1000 \mu \mathrm{g} / \mathrm{mL}$, and $0.868 \pm 0.009$ for $2000 \mu \mathrm{g} / \mathrm{mL}, p=0.0753$ ) than the control cells 
$(0.944 \pm 0.014)$, probably reflecting the inhibitory effect caused by $24 \mathrm{~h}$ of preincubation with the drug $(p=0.0395, n=17,95 \% \mathrm{CI}=-0.08857$ to -0.003434 for gabapentin $1000 \mu \mathrm{g} / \mathrm{mL}$, and $p<0.0001, n=28,95 \% \mathrm{CI}=-0.1134$ to -0.04461 for gabapentin $2000 \mu \mathrm{g} / \mathrm{mL}$ vs. control, respectively).

The summarized data showing the absolute value of change (experimental condition baseline) of transient calcium responses are shown in Figure 7B. After exposing the cells incubated with gabapentin with $130 \mathrm{mM} \mathrm{KCl}$, calcium transients were significantly reduced ( $p<0.0001$ for both doses) compared to cells under the control condition (without gabapentin), which showed a marked increase in calcium influx (ratio $340 / 380 \mathrm{~nm}$ : $0.034 \pm 0.005, n=17$ cells, $95 \% \mathrm{CI}=-0.1890$ to -0.09903 for gabapentin $1000 \mu \mathrm{g} / \mathrm{mL}$; and ratio $340 / 380 \mathrm{~nm}: 0.024 \pm 0.003, n=28$ cells, $95 \% \mathrm{CI}=-0.1887$ to -0.1193 for gabapentin $2000 \mu \mathrm{g} / \mathrm{mL}$ vs. control, ratio 340/380 nm: $0.178 \pm 0.016, n=32$ cells). After returning to baseline conditions, exposure to $10 \mathrm{mM} \mathrm{CaCl}_{2}$ induced a calcium influx that was not significantly different from control cells (ratio 340/380 nm: $0.131 \pm 0.009, p=0.1077$, $n=17$ cells, $95 \% \mathrm{CI}=-0.005664$ to 0.05566 for gabapentin $1000 \mu \mathrm{g} / \mathrm{mL}$; and $0.092 \pm 0.009$, $p=0.3079, n=28$ cells, $95 \% \mathrm{CI}=-0.04124$ to 0.01324 for gabapentin $2000 \mu \mathrm{g} / \mathrm{mL}$ vs. control, ratio $340 / 380 \mathrm{nm:} 0.106 \pm 0.010, n=32$ cells). These results indicate the persistence of calcium homeostatic mechanisms, suggesting that cells were still functional even after treatment with gabapentin.

\section{Discussion}

According to our results, gabapentin administration promoted an antihyperalgesic effect and tumor growth inhibition in a cancer-induced pain model employing male mice. These effects were observed in our in vivo and in vitro experiments, suggesting that in addition to controlling mechanical and thermal hypersensitivity caused by tumor engulfing of the sciatic nerve, gabapentin also regulates tumor proliferation, CCL2 secretion, and calcium influx. These results indicate that modulation of disrupted calcium entrance may be a potential target for cancer pain therapies.

Calcium influx can be considered a common denominator for the in vivo and in vitro effects observed herein. Ionic calcium is considered a universal second messenger and an essential regulator of the mitotic signal cascade, the cell cycle [12-14], and the cell's proliferation mechanisms [33]. Likewise, calcium entry is also a key mediator of hypersensitivity in neurons of the pain pathway. The ultimate source of calcium is the extracellular microenvironment [11], and for that reason, its flow into the cells through specific membrane channels is fundamental for a correct cell function.

Calcium-dependent signaling is frequently deregulated in cancer cells and primary afferents compromised by a lesion (here for a surrounding tumor). In those scenarios, VGCCs play a crucial role in remodeling ion homeostasis. Hence, neuromodulators such as gabapentin-which regulates calcium entry through most VGCCs-may become a drug of choice to control hyperalgesia and tumor proliferation simultaneously. Available evidence indicates that calcium signaling plays a key role in melanoma viability [11,34-36], and our results are also consistent with this observation.

In the present study, we used a murine model of cancer-induced pain; it involved the inoculation of a fluorescent melanoma cell line in the vicinity of the sciatic nerve. Due to its fluorescence properties and the use of in vivo imaging techniques, we monitored tumor growth through the skin before it could be detected by thigh palpation, and studied early behavioral changes in advance. The tumor grew in place, limited to the outside of the epineurium, without infiltrating the nerve (at least during our time course). Our paradigm has been recently used [3], and resembled a rare, but not impossible, case of melanoma neurotropism $[37,38]$ that causes tumor-related hyperalgesia in the inoculated hind paws (sciatic nerve's territory). Additionally, we performed in vitro experiments to evaluate the effects of gabapentin on the proliferation of the melanoma cell line B16-BL6/Zs green, CCL2 secretion, and calcium influx. 
Hyperalgesia is one of the most common and persistent symptoms associated with cancer, and multiple factors may contribute to the tumor-related increased nociception. Some of these may be attributable to the tumor itself, such as the release of peptides and other algogens, directly affecting sensory neurons $[39,40]$. Those neuroactive chemicals may also be released by immune cells in response to tumor-evoked damage to surrounding tissue, mechanical compression of nerves, or ischemia [41]. Several mechanisms underlying cancer-induced hyperalgesia may also involve components shared by neuropathic pain [42,43]; hence, the administration of agents commonly used to relieve pain-associated neuropathy may be similarly helpful in alleviating cancer-induced hyperalgesia.

Our behavioral results indicate that gabapentin significantly inhibits tumor growth and controls the increase in nociception. Before the onset of treatment, tumor-bearing animals showed emerging signs of mechanical allodynia and thermal hyperalgesia-even before the tumor was evident-which frequently occurred around day 9 post-inoculation. However, by day 3 , imaging studies revealed small tumors already growing in the inoculated thighs. In saline control animals, hypersensitivity progressively increased until the end of the experiment and, by day 17, tumors reached the most extensive perimetral area. In the gabapentin group, as soon as the therapeutic protocol was started (day 11), the animals recovered their baseline level of response in the behavioral tests and, $12 \mathrm{~h}$ after drug administration, tumor mass significantly reduced its progression, appearing fragmented via imaging techniques. In mice receiving the preventive treatment, gabapentin induced a significant inhibition of tumor growth as soon as treatment started, and those animals did not show the typical initial increase in hyperalgesia. Nevertheless, after discontinuing treatment, tumor growth and hyperalgesia remained under control for four additional days, indicating the possible existence of a residual effect on cancer-induced nociception and cellular proliferation. These results suggest that cancer can and should be treated in advance to guarantee maximum control of the nociceptive symptoms and tumor growth.

Gabapentin-a derivative of the inhibitory neurotransmitter GABA—was initially designed as a GABAmimetic agent licensed to treat refractory epilepsy. It has gained wide recognition for its efficacy in controlling chronic pain syndromes, especially neuropathic pain [24], with minimal side effects. Even though gabapentin may induce dose-dependent motor incoordination and sedation at higher doses [44-46], in the present experiments, no sedation, catalepsy, or motor impairment was observed. The discovery of one specific binding site for gabapentin in the Cav $\alpha 2 \delta$ subunit stimulated characterization of VGCCs in the drug's clinical activity $[2,19,24,43,47-50]$. Current evidence favors the existence of four isoforms of Cav $\alpha 2 \delta$ subunit, only two of which (Cav $\alpha 2 \delta 1$ and Cav $\alpha 2 \delta 2)$ bind gabapentin [2] in L-, N- and P/Q-type calcium channels [24,49]. This binding promotes inhibition of calcium inward currents [51] and, consequently, leads to a reduced release of glutamate $[24,52,53]$ and other excitatory molecules such as substance $P[24,54]$ and NMDA [55], with the expected attenuation of postsynaptic excitability $[2,19,24,47,56,57]$. In this study, we observed a similar inhibition of calcium influx in murine melanoma (non-excitable) cells treated with gabapentin. Interestingly, while the Cav $\alpha 2 \delta 1$ subunit has been involved with the effects of gabapentin against neuropathic pain, the Cav $\alpha 2 \delta 2$ subunit seems to mediate some of the adverse effects of gabapentinoids, such as dizziness and sedation [58]. Hence, the chance of observing unwanted side effects should increase with higher doses, due to the increased probability of binding to the Cav $\alpha 2 \delta 2$ subunit.

Furthermore, the reduction of glutamate release induced by gabapentin might modulate the occupancy of the metabotropic glutamate receptor 1 (GRM1), as well as the NMDA receptor, which seems to induce spontaneous melanoma development in vivo [59-61] and melanoma growth [62]. On the other hand, glutamate, acting through NMDA receptors, has also been implicated in changes of the natural killer cell response [63], which is endogenously responsible for reducing tumor activity.

Nerve damage is associated with changes in the electrophysiological and neurochemical properties of injured primary afferent neurons that cause the expression of a gain-of-function phenotype, resulting in activation at lower depolarizing membrane poten- 
tials. For example, DRG neurons showed increased ipsilateral expression of the Cav $\alpha 2 \delta 1$ subunit following partial sciatic nerve ligation [64]; this upregulation influences the processing of sensory information via calcium-dependent mechanisms such as neurotransmitter release and neuronal excitability. In those cases, gabapentin reverted to allodynic behavior and inhibited peripheral ectopic discharges from injured nerve sites [65]. Whether or not similar changes can be promoted by a tumor growing around a nerve is certainly worthy of consideration. Interestingly, in a murine model of cancer pain, the implantation of fibrosarcoma cells into and around the calcaneus bone caused tumor-evoked heat hyperalgesia and sensitization, with ongoing spontaneous $C$ nociceptor activity and increased widedynamic-range (WDR) neuron discharge [40,41]. In that model, tumor-evoked sensitization was associated with increased mRNA levels for the Cav $\alpha 2 \delta 1$ subunit, and pretreatment with gabapentin blocked mechanical hyperalgesia [10].

A possible element that may contribute to explain the correlation between sensitization and Cav $\alpha 2 \delta 1$ subunit overexpression is CCL2. Chemokines have been implicated in developing and maintaining pain [25], and CCL2 immunoreactivity was found in animals bearing a tumor [10]. Several lines of evidence suggest that CCL2 is a mediator of persistent hyperalgesia. CCL2 depolarizes DRG neurons in several models of neuropathic pain [10]. Moreover, CCL2 and its CC chemokine ligand-receptor 2 (CCR2) became upregulated in neurons after the DRG's chronic compression [66,67]. Additionally, the development of mechanical allodynia was blocked in neuropathic CCR2 knockout mice [68], and the treatment of DRG neurons in vitro with CCL2 obtained from fibrosarcoma culture supernatants increased the amount of mRNA for the Cav $\alpha 2 \delta 1$ subunit. These findings suggest that CCL2 released from tumor cells might promote phenotypic changes in sensory neurons, including overexpression of accessory subunits in VGCCs that likely underlie the mechanical hyperalgesia in the fibrosarcoma cancer model [10], and perhaps contribute to explaining the mechanical allodynia and thermal hyperalgesia also observed in our animals. We found that B16-BL6/Zs green melanoma cells secrete CCL2 spontaneously; thus, the tumor mass could directly affect the excitability of nociceptive neurons in our animals, and might induce the upregulation of CCL2 receptors (CCR2 and CCR4), as has been previously suggested [69].

The expression of VGCCs has been reported in melanoma cells, which supports their roles in tumorigenesis and tumor progression [15]. Aberrant expression and abnormal activity of specific ion channels were associated with increased cancer aggressiveness [70,71]. Therefore, pharmacological regulation of channel activity might offer protection against several types of cancers [15]. Melanoma cells express channel isoforms belonging to the Cav1 (which mainly encodes high-voltage-activated L-type channels) and Cav2 (which encodes high-voltage-activated P/Q-type, N-type, and R-type channels) gene families [11]. Hence, agents that modulate these calcium channels—such as gabapentin-may become a therapeutic option to prevent melanoma growth, migration, or invasion-and, simultaneously, tumor-related hyperalgesia.

The fact that CCL2 is released by a compressed nerve [66,67] —and, constitutively, by our melanoma cell line-may explain why $12 \mathrm{~h}$ after starting the gabapentin administration in the therapeutic protocol, a significant decrease in tumor size was observed. As mentioned before, CCL2 induces overexpression of the Cav $\alpha 2 \delta 1$ subunit in the VGCCs of primary afferents [10] and melanoma cells [15], as well as overexpression of CCL2 receptors (CCR2 and CCR4) [69]. These elements should improve the gabapentin binding and, consequently, its related effects on the spatial and temporal organization of calcium signaling and tumor growth inhibition. The combined overexpression of these elements over the course of the experiments should augment tissue distribution of the binding sites for gabapentin, hence promoting the inhibition of calcium-dependent tumorigenic pathways, such as in cell proliferation.

In our in vitro experiments, we studied calcium entry under $\mathrm{KCl}$-mediated depolarizing conditions. In B16-BL6 melanoma cells, gabapentin inhibited calcium influx compared to control cells (without gabapentin) —an effect probably caused by the binding 
of gabapentin to the Cav $\alpha 2 \delta$ subunit of most VGCCs. However, calcium entry promoted by the addition of $\mathrm{CaCl}_{2}$ to the bath was not affected by gabapentin treatment, suggesting the participation of other calcium entry mechanisms present in non-excitable cells, such as TRP channels, T-type VGCCs (belonging to $\mathrm{Cav} 3$ ), and the store-operated calcium entry (SOCE) [33,72], among others. Hence, a potential combination of gabapentin with a pharmacological channel regulator (i.e., a SOCE inhibitor) is worthy of study to verify an improvement in controlling cell proliferation in this and other tumor models.

Cell proliferation and survival were also studied in our in vitro experiments. In B16BL6/Zs green melanoma cells, gabapentin inhibited proliferation in a dose-dependent manner, inducing a cytostatic effect since viability was not affected, as shown by an evident proliferation relapse after washing gabapentin out of the wells (even though a residual effect of the previous incubation with gabapentin was still present). These in vitro results may contribute to explaining the effect of gabapentin on tumor growth observed in our in vivo experiments, and support the hypothesis that malignant cells exhibit a strong dependence on calcium influx for disease progression [73]. Such inhibition may result strategically when surgery, or radio- or chemotherapy, becomes necessary.

\section{Materials and Methods}

\subsection{Animals}

Healthy naïve male adult C57BL/6 mice of 20-30 g ( $n=10$ /group, for a total of 40 mice, including experimental and control animals) were used. This number was chosen based on power analysis (alpha $=0.1$ and power $=0.9$, suggesting around 9 animals for an expected analgesic effect of 1.0). To avoid possible hormonal effects, only male mice were included in the study. As indicated in Figure 8, for each experiment (therapeutic or preventive protocol), the study included two groups: (a) control animals: receiving IP saline; and (b) experimental animals: receiving IP gabapentin. Both hind paws were studied in each animal so that the contralateral non-inoculated limb represented an internal control. The animals were bred at the Central Animal Facility of the Instituto Venezolano de Investigaciones Científicas (IVIC).

Mice were kept in groups of five in plastic boxes with a microisolator filter on top. The colony room temperature was kept constant at $22{ }^{\circ} \mathrm{C}$, with 25 air changes per hour. Humidity was also regulated, and light/dark cycles lasted $12 \mathrm{~h}$ each. All experiments were performed during the light cycle. Bedding for each cage and food (Ratarina, Alimentos Protinal, C.A., Valencia, Venezuela) were sterilized in a cobalt-60 plant at the IVIC. Water was delivered after a double-filtration process and, like the food, was available ad libitum. All experiments were performed in the Laboratorio de Neurofisiología, Centro de Biofísica y Bioquímica (CBB) at the IVIC, under the supervision (group allocation, experimental procedure, outcome assessment, and data analysis) of a responsible experimenter (V.T., corresponding author), and with the assistance of our veterinary staff to guarantee the health status of the animals. To minimize potential confounders (order of treatments, protocols, or animal location) a Google form was followed every experimental day. Fever, weight loss, decrease of water intake, sedation, motor impairment, catalepsy, spontaneous pain, or infection were continuously used as criteria established a priori to exclude animals during the study. However, no animals were excluded, and no unexpected adverse events were observed. At the end of each assay, mice were euthanized with an overdose of sodium thiopental (SM Pharma Laboratories, Caracas, Venezuela), following the recommendations of the Panel on Euthanasia of the American Veterinary Medical Association [74] and the Code of Practice for the Housing and Care of Animals Used in Scientific Procedures [75]. 


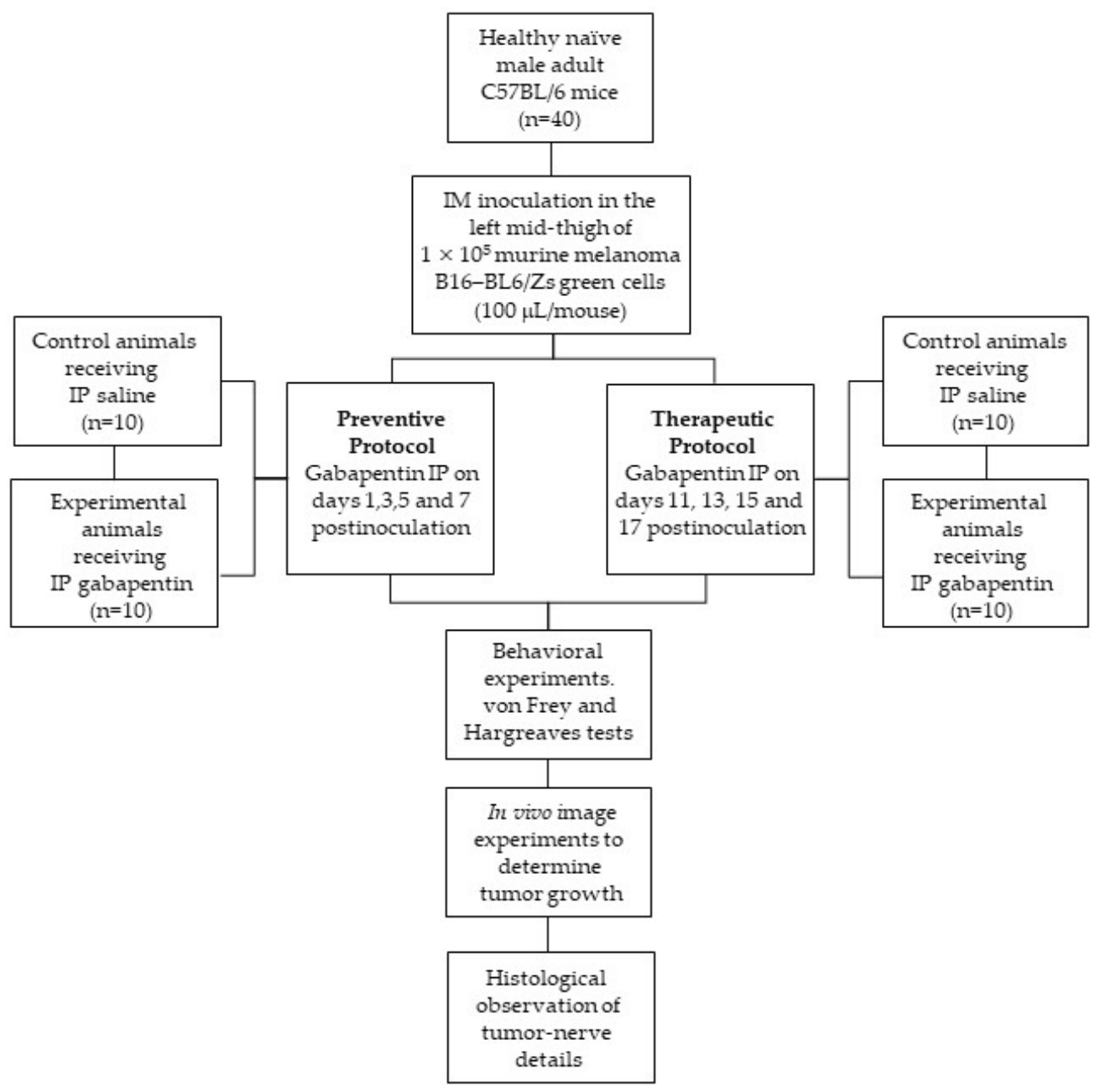

Figure 8. Summary of the in vivo experimental protocol.

\subsection{Drug Used}

Gabapentin-1-(aminomethyl)-cyclohexaneacetic acid-was kindly donated by Pfizer, Inc., New York, NY, USA. A dose of $100 \mathrm{mg} / \mathrm{Kg}$ was chosen based on previous works [76-78] for intraperitoneal (IP) injection. The drug was in its pure state, which avoided additional experiments to monitor the potential effects of excipients. This was the lowest effective dose when used in our acute pilot experiments with C57BL/ 6 tumor-bearing mice (data not shown here for space reasons). Its maximum effect (at $30 \mathrm{~min}$ post-injection) was determined in previous acute experiments of 120-min duration; in those experiments, the behavioral tests (see below) were applied with an interval of $15 \mathrm{~min}$ between timepoints. During this observation period, neither sedation nor motor impairment was observed in the injected mice, similarly to a previous report from another group [76]. Gabapentin was dissolved in physiological solution $(0.9 \% \mathrm{NaCl}$; Laboratorios Behrens, Caracas, Venezuela), and $0.2 \mathrm{~mL}$ was the injection volume. An equivalent volume of saline was administered IP to control animals.

\subsection{Experimental Model}

Our experimental model was employed here and previously [3] to quantify the nociceptive behavioral consequences of a tumor-nerve interaction, and its possible pharmacological management. As shown in Figure 8, this involved the use of murine melanoma B16-BL6/Zs green cells (kindly donated by Dr. Frank Marini, MD Anderson Cancer Center, Houston, TX, USA) - a transfected cell line that expresses the green fluorescent protein (GFP), derived from the highly invasive B16-BL6 melanoma line that has also 
been employed in a skin cancer pain model in C57BL/6 mice [5]. After light sedation, obtained by placing each animal in a ventilatory capsule containing halothane in oxygen, C57BL/ 6 mice were inoculated once, intramuscularly (IM), in the left midthigh $\left(1 \times 10^{5}\right.$ cells $/ 100 \mu \mathrm{L} /$ animal $)$, in the immediate vicinity of the sciatic nerve, as described in a neuropathic cancer pain model already published [6]. Halothane (Hoechst Marion Roussel, S.A., Caracas, Venezuela) was chosen since it provides ideal anesthesia for small animals, avoiding the risk of hypoxia and a rapid awakening time. The cell line was cultured, using conventional techniques, in low-glucose Dulbecco's modified Eagle's medium (DMEM) (Sigma-Aldrich Laboratories, Saint Louise, MO, USA) with 5\% fetal calf serum (Invitrogen Corporation, Carlsbad, CA, USA), 1\% penicillin-streptomycin (Sigma-Aldrich Laboratories), and 1\% glutamine (Sigma-Aldrich Laboratories), maintained at $37^{\circ} \mathrm{C}$ and $5 \% \mathrm{CO}_{2}$ in a humid chamber.

\subsection{Drug Administration Protocol}

To evaluate the effects of gabapentin, each group of mice received a single IP injection of the drug or saline from a blinded experimenter, always at 09:00 a.m., every other day, for 4 days, to minimize the effect of excessive handling. Both experimental and control animals were randomly assigned. Each animal was identified with a number and allocated to its respective group using a random number generator (Decision Analyst STATS 2.0, www. decisionanalyst.com, accessed on 18 January 2019). The drug was administered on days 11, 13,15 , and 17 post-inoculation in the therapeutic protocol. These days corresponded to the maximum expression of tumor growth and significant changes in pain threshold [3]. The preventive treatment was carried out on days 1,3,5, and 7 post-inoculation, beginning before the primary tumor was palpable, and before the appearance of changes in pain threshold [3] (Figure 8). This latter protocol was intended to assess the possible existence of a "critical time window" for treatment, before the onset of pain signs and before the appearance of superficial morphological changes.

\subsection{Behavioral Tests}

On the experimental days, the von Frey and Hargreaves tests were applied to the plantar region of the hind paws (sciatic nerve's territory), and withdrawal responses were observed before (baseline, BL) and after inoculating the cell line, as well as before and after drug or control vehicle administration. The von Frey test involves using a series of nylon monofilaments (Touch-Test Sensory Evaluator, Semmes-Weinstein monofilaments, Stoelting, Wood Dale, IL, USA) into the paw of each animal to apply a specific bending pressure depending on the calibrated filament employed. This pressure was expressed in grams $(\mathrm{g})$. The animals were allowed to habituate in the chamber for a 5-min period. After that, the filaments were applied in ascending or descending sequence to determine the minimum pressure (threshold) that evoked a clear withdrawal response. This procedure was performed three times, with 3 min between tests, so that the results expressed in the graphs are an average of these measurements. The response of the contralateral limb (not inoculated) served as an internal control. The Hargreaves test involves placing each animal in a paw analgesiometer (Hargreaves, IITC Life Science, Series 8, Woodland Hills, CA, USA). The device has a transparent plastic chamber with a glass floor preheated to $28-30{ }^{\circ} \mathrm{C}$. The animals remained in the chamber for a 5 -min period of habituation. A thermal nociceptive stimulus $\left(50^{\circ} \mathrm{C}\right)$ was then applied, using an incandescent light source with an illumination area of $7 \mathrm{~mm}^{2}$. The time (latency) it took the animal to withdraw its paw from the radiant heat beam was determined. The cutoff time was $30 \mathrm{~s}$. This procedure was applied three times, with a 5-min separation between trials, so that the results shown in the graphs represent an average of the three measures. Again, the unaffected contralateral paw served as an internal control. 


\subsection{Determination of Tumor Growth}

Tumor growth was monitored in control and experimental animals using a Kodak FX In-Vivo Image Station (Carestream Inc., Woodbridge, CT, USA) (Figure 8). The equipment allowed the co-registration of the cell line's fluorescence signal (ex465 and em535 nm filters for $30 \mathrm{~s}$ ) with anatomical X-ray imaging ( $35 \mathrm{Kvp} / 30$-s exposure, employing the same field of view and focal plane as the fluorescence image). All measurements were performed during the experimental days in lightly sedated animals (halothane vapors, see above) to minimize the stress associated with handling and capture a clear and stable image. Additionally, mice were placed onto a warmed stage inside the security cabinet for the duration of the exposure. Images were taken $12 \mathrm{~h}$ after gabapentin administration due to limited access to the equipment. Changes were detected only in the left mid-thigh of the live animals, even before superficial morphological changes could be detected via palpation. Images were obtained without euthanizing the animals for the whole experimental period, which reduced the number of animals in the study. Regions of interest (ROIs) from displayed images were identified and used to calculate the perimetral tumor area $\left(\mathrm{mm}^{2}\right)$. At the end of the process, the fluorescence images were pseudocolored to improve the contrast using the Kodak Molecular Imaging v4.5 software that comes with the equipment.

\subsection{Histology}

At the end of the experiments (day 17), mice were euthanized in a $\mathrm{CO}_{2}$ chamber, and tumor-bearing thighs were removed from each animal, fixed in $10 \%$ formalin for at least $24 \mathrm{~h}$, and maintained in 70\% ethanol before decalcification with Osteomol (Merck, Darmstadt, Germany) for $72 \mathrm{~h}$. Subsequently, tissue was processed and embedded in paraffin using an automatic processor (Leica Microsystems TP 1020, Nussloch, Germany). For analysis purposes, 5-micron paraffin sections were stained with hematoxylin and eosin (H-E; Sigma-Aldrich, St. Louis, MO, USA) in an automatic stainer (Leica Microsystems Autostainer XL). Fluorescence observations from different fields at 400x and 2000x magnification were carried out using an inverted fluorescence microscope (DMIL LED, Leica Microsystems, Wetzlar, Germany) coupled with a camera (DFC310 FX, Leica Microsystems). Images were processed using the Leica LAS AF software, version 4.4 (Leica Microsystems).

\subsection{In Vitro Proliferation Assays}

The effect of gabapentin was also studied in vitro using conventional techniques, as mentioned previously. Murine B16-BL6/Zs green melanoma cells were seeded into 96-well flat-bottom tissue culture microplates $\left(1 \times 10^{3}\right.$ cells/well, Falcon, Becton Dickinson, NJ, USA) and incubated for $24 \mathrm{~h}$ to allow adherence to the plate. Thereafter, six different concentrations of the drug $(1,10,50,100,1000$, or $2000 \mathrm{mg} / \mathrm{mL})$ were tested (Figure 9); these concentrations were chosen based on previous works [79-81]. According to pharmacokinetic studies, after the administration of a 400-mg gabapentin tablet to a human, its maximum concentration in plasma reached approximately $20 \mu \mathrm{M}$ [80]. In this study, the cytostatic effect of gabapentin was determined using $2000 \mu \mathrm{g} / \mathrm{mL}$ as the highest dose-which is equivalent to $11.68 \mu \mathrm{M}$-and compared to the control cell cultures without gabapentin. According to a recent study [81], this concentration is similar to a third of the maximum daily dose of gabapentin $(3600 \mathrm{mg})$. Cell proliferation was monitored $96 \mathrm{~h}$ later using an inverted fluorescence microscope (DMIL LED, Leica Microsystems) coupled with a camera (DFC310 FX, Leica Microsystems). Images were processed using the Leica LAS AF software, version 4.4 (Leica Microsystems). 


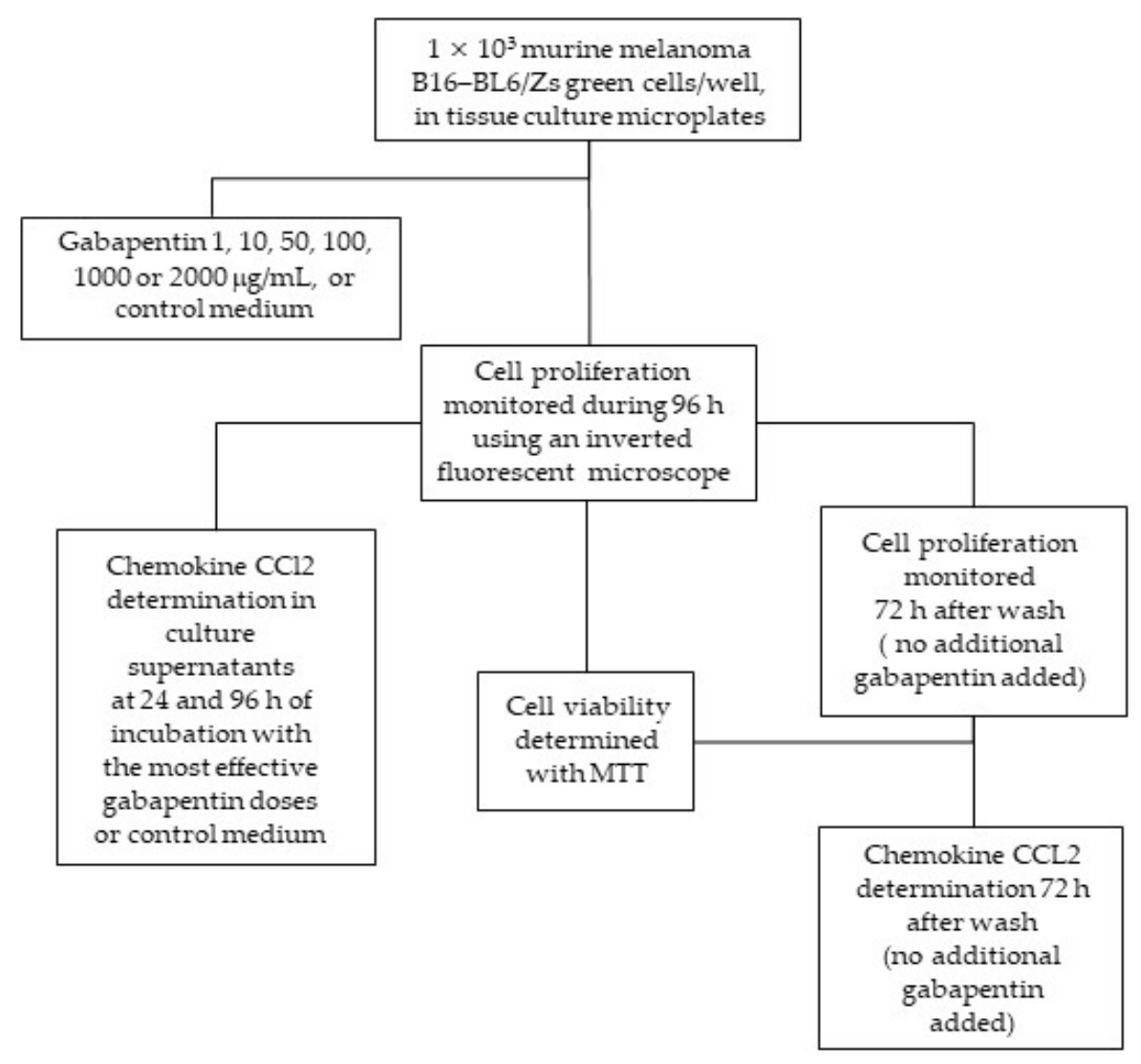

Figure 9. Summary of the in vitro experimental protocol.

The antiproliferative effect of the drug was studied in another set of culture plates. After completing the incubation time, gabapentin was washed out twice with $100 \mu \mathrm{L} /$ well of phosphate-buffered saline (PBS), and the wells were replenished with culture media. Again, cell proliferation was monitored $72 \mathrm{~h}$ later. MTT (3-(4-5-dimethylthiazol-2-yl)2,5 diphenyltetrazolium bromide; Sigma-Aldrich Laboratories, MO, USA; $2.5 \mathrm{mg} / \mathrm{mL}$, $25 \mathrm{~mL} /$ well) was added, and plates were incubated for $4 \mathrm{~h}$ to test the viability of the cells after the drug challenge. When a cell is alive, MTT should be incorporated, and formazan crystals must be metabolically produced via a reduction process so that the amount of crystals reflects the number of viable cells present in the culture well [82]. Crystals were dissolved with a solubilizing solution (100 $\mathrm{LL} /$ well) containing $20 \%$ SDS in a 1:2 solution of N-N-dimethyl formamide (Fisher Scientific Co., Pittsburgh, PA, USA) in distilled water. Plates were incubated overnight in the dark and quantified spectrophotometrically (570 nm) using an ELISA plate reader (EL-307C; BioTek Instruments, Winooski, VT, USA). The results were expressed as a percentage of cellular proliferation compared to non-treated cells $(100 \%$ proliferation). Each well condition was replicated three times per experiment, so that the results shown in the graphs represent an average of three measures.

\subsection{Chemokine CCL2 Determination}

Culture supernatants obtained from the B16-BL6/Zs green proliferation assays (see above) at 24 and $96 \mathrm{~h}$ of incubation with 1000 or $2000 \mu \mathrm{g} / \mathrm{mL}$ of gabapentin (most effective doses) were studied (Figure 9). Moreover, we included supernatants from culture plates after gabapentin was washed out, which were maintained with fresh culture medium for an additional 72-h period, as well as control supernatants from plates without gabapentin. A commercially sandwich enzyme-linked immunosorbent assay kit (ELISA Max ${ }^{\mathrm{TM}}$ Standard Sets, BioLegend, San Diego, CA, USA) was used to determine the chemokine CCL2 protein concentration $(\mathrm{pg} / \mathrm{mL})$ on enzyme-linked immunosorbent assay microplates (MaxiSorp, Nunc $^{\mathrm{TM}}$, Apogent, Portsmouth, NH, USA). CCL2 concentration was estimated based on an 
appropriate internal standard curve using a recombinant murine chemokine. The results represent the mean of three independent assays, conducted in triplicate and expressed as the mean \pm SEM.

\subsection{Calcium Influx Measurements}

Murine B16-BL6 melanoma cells (kindly donated by Dr. Peter Taylor, Centro de Medicina Experimental, IVIC, Caracas, Venezuela) were plated at a density of $2 \times 10^{5}$ cells in a Petri dish (Sigma-Aldrich Laboratories) containing a glass coverslip (Corning Inc., New York, NY, USA) to determine the effect of gabapentin on calcium influx. Cells were allowed to proliferate for $24 \mathrm{~h}$, with or without gabapentin (1000 or $2000 \mu \mathrm{g} / \mathrm{mL})$, in low-glucose DMEM supplemented with 10\% FCS, plus $40 \%$ melanoma-cell-conditioned medium, at $37^{\circ} \mathrm{C}$ in a humidified atmosphere of $5 \% \mathrm{CO}_{2}$ (Figure 10).

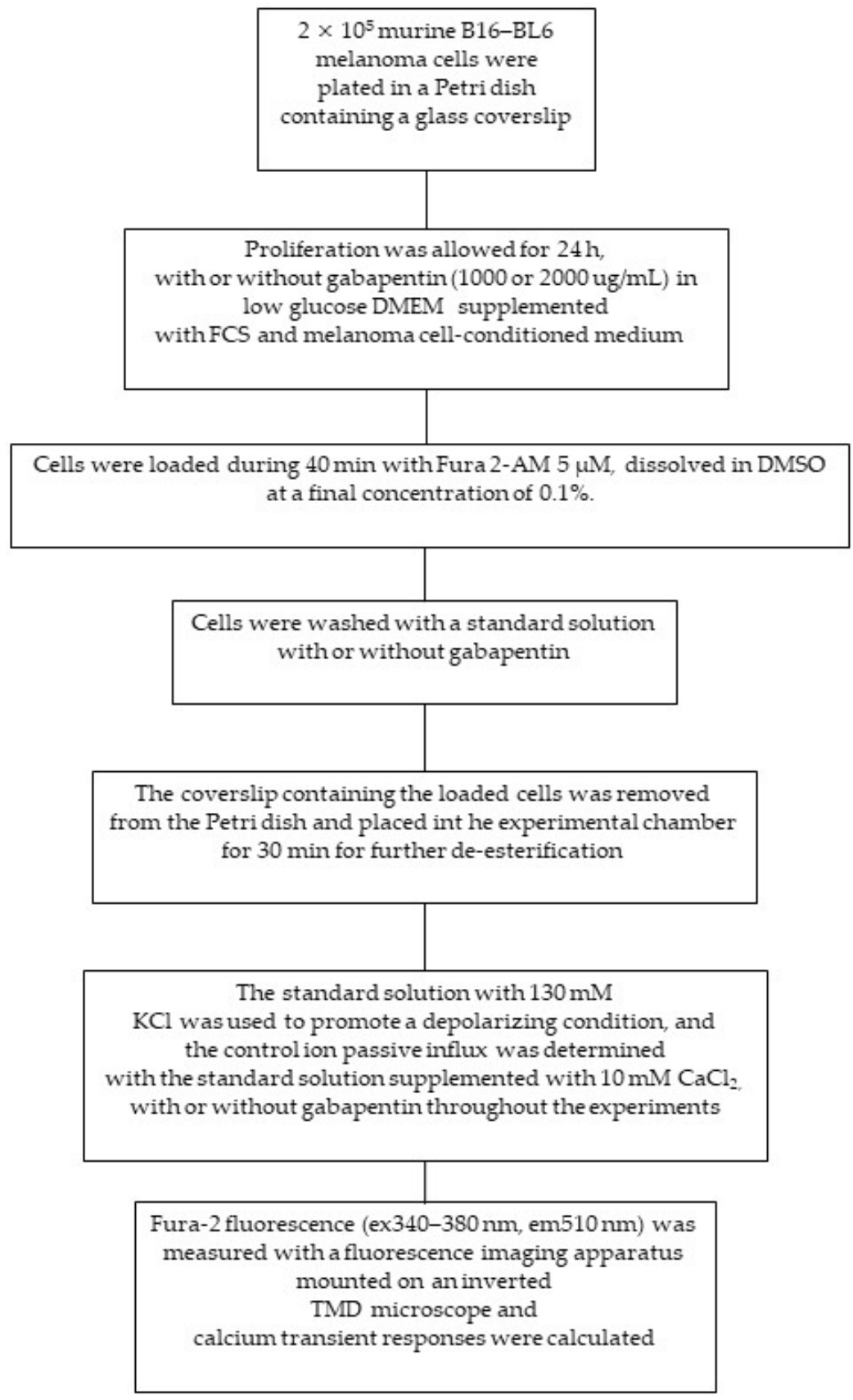

Figure 10. Summary of the in vitro calcium influx experiments. 
Later, B16-BL6 cells were loaded with $5 \mu$ M Fura-2/ AM (Invitrogen, Molecular Probes, Eugene, OR, USA) - the high-affinity calcium-selective fluorescent intracellular indicator, dissolved in DMSO at a final concentration of $0.1 \%$ for $40 \mathrm{~min}$, at $37^{\circ} \mathrm{C}$, in the dark. Then, cells were washed with standard solution $(130 \mathrm{mM} \mathrm{NaCl}, 5 \mathrm{mM} \mathrm{KCl}, 1 \mathrm{mM} \mathrm{CaCl}, 1 \mathrm{mM}$ $\mathrm{MgCl}_{2}, 10 \mathrm{mM}$ HEPES, $10 \mathrm{mM}$ glucose, $\mathrm{pH}$ 7.4; used as baseline condition), with or without gabapentin (1000 or $2000 \mu \mathrm{g} / \mathrm{mL})$, throughout the recordings. The coverslip containing the loaded cells was then removed from the Petri dish and placed in an experimental chamber for $30 \mathrm{~min}$ to allow further de-esterification. The standard solution with $130 \mathrm{mM} \mathrm{KCl}$ was used to promote a depolarizing condition. The control ion passive influx was determined with the standard solution supplemented with $10 \mathrm{mM} \mathrm{CaCl}_{2}$.

Fura-2 fluorescence (ex340-380 nm, em510 nm) was measured with a fluorescenceimaging apparatus (IonOptix Co., Milton, MA, USA) mounted on an inverted Nikon Diaphot TMD microscope (Tokyo, Japan). For Fura-2 measurements, the light from a 100-W xenon lamp was filtered alternating 340/20- and 380/18-nm interference filters (Chroma Technology Corp., Rockingham, VT, USA). The resultant fluorescence was passed through a 400-nm dichroic mirror, filtered at 510/40 nm (Chroma Technology Corp., Rockingham, VT, USA), and collected using an intensified CCD camera. Fluorescence images were taken at a 33-ms/frame rate, digitalized, and analyzed using the IonOptix 5.0 software (IonOptix Co.). Results were graphed as the fluorescence ratio $(340 / 380 \mathrm{~nm})$ versus time (s) using Origin 8.1 software [83]. The absolute value of change of calcium transient responses was calculated by subtracting each experimental condition value from its baseline, and expressed as Fura-2 fluorescence ratio $(340 / 380 \mathrm{~nm})$. The murine melanoma cell line B16-BL6 was used in these experiments instead of the B16-BL6/Zs green cell line, since GFP interferes with the Fura-2 fluorescence signal. Previous work in our laboratory indicates that these cell lines are similarly affected by gabapentin in terms of in vivo tumor growth, as well as in vitro proliferation and CCL2 secretion.

\subsection{Statistical Analysis}

The results were reported as the mean \pm SEM. The Kolmogorov-Smirnov test and Levene's median test were performed to verify data normality. Then, differences between groups were evaluated by applying the Mann-Whitney $U$-test or the Kruskal-Wallis test. Differences were acknowledged as statistically significant when $p \leq 0.05$. Confidence intervals were also included throughout the results section. Due to the absence of any exclusions, all of the animals were included in the analysis. The statistical program used was GraphPad Prism version 5.0 (GraphPad Software, San Diego, CA, USA).

\section{Conclusions}

Based on these results, the modulation of pathophysiological calcium signaling might represent an appropriate therapeutic strategy to control tumor development and progression, as well as tumor-induced hypersensitivity. The expected functional consequences of channel regulation must act not only on tumor parameters such as growth, migration, or invasion, but also on their sensorial and behavioral implications. However, careful selection of the ion influx modulator must be well thought out, because calcium channels are ubiquitously expressed in different tissues, playing relevant roles in normal cell function. Here, we present the alternative of gabapentin which, acting on Cav $\alpha 2 \delta$-bearing VGCCs of melanoma cells and primary afferents, seems to exert a concomitant antihyperalgesic and antitumor effect without apparent adverse effects, suggesting that this drug should be considered not merely as a coadjuvant, but also as a pharmacological regulator of calcium remodeling in pathophysiological conditions.

Author Contributions: B.E.B. and V.T. conceived and designed the study; P.B. was in charge of calcium influx methodology; M.A.G., Y.M.D.G., S.D., G.B., V.A.T.-B., L.B. and G.D.-S. performed the data collection; B.E.B., M.A.G., Y.M.D.G., S.D., G.B., V.A.T.-B., G.D.-S. and V.T. analyzed the data; B.E.B. and V.T. wrote the paper. All authors have read and agreed to the published version of the manuscript. 
Funding: This work was supported by the Mission Science Program Grant Project 2007000881 from the Ministerio del Poder Popular para Ciencia y Tecnología, and by a grant from the company ENI DACION-BV, according to the Law on Science, Technology, and Innovation (LOCTI) of the Bolivarian Republic of Venezuela, to B.E.B. and V.T. These funding sources were not involved in any of the stages of this research.

Institutional Review Board Statement: This study was conducted in accordance with the guidelines of the Declaration of Helsinki, and an experimental protocol (including the research question, key design features, and analysis plan) was approved by the Bioethical Committee for the Use of Experimental Animals (COBIANIM) of the IVIC (protocol registration code 7809-I, 8 July 2009). Following internal regulations, this protocol was submitted before starting the experiments. All of the procedures complied with the ARRIVE 2.0 guidelines and the Code of Practice for the Housing and Care of Animals Used in Scientific Procedures. At all times, full efforts were made to optimize mouse survival, and to minimize the number of animals used and their suffering.

Data Availability Statement: All study data are available upon reasonable request after ethics clearance and approval by all coauthors for well-defined questions aligned with the overall research objectives.

Acknowledgments: The authors wish to give thanks for the assistance of the veterinary staff of the IVIC's Central Animal Facility.

Conflicts of Interest: The authors declare no conflict of interest.

\section{References}

1. Foley, K.M. How well is cancer pain treated? Palliat. Med. 2011, 25, 398-401. [CrossRef] [PubMed]

2. Sykes, N.; Bennett, M.; Yuan, C.-S. Clinical Pain Management: Cancer Pain, 2nd ed.; Hodder Arnold: London, UK, 2008.

3. Brito, B.E.; Vazquez, E.; Taylor, P.; Alvarado, Y.; Vanegas, H.; Millan, A.; Tortorici, V. Antinociceptive effect of systemically administered dipyrone (metamizol), magnesium chloride or both in a murine model of cancer. Eur. J. Pain 2017, 21, 541-551. [CrossRef] [PubMed]

4. Kuraishi, Y. Effects of morphine on cancer pain and tumor growth and metastasis. Nippon Rinsho. 2001, 59, 1669-1674. [PubMed]

5. Sasamura, T.; Nakamura, S.; Iida, Y.; Fujii, H.; Murata, J.; Saiki, I.; Nojima, H.; Kuraishi, Y. Morphine analgesia suppresses tumor growth and metastasis in a mouse model of cancer pain produced by orthotopic tumor inoculation. Eur. J. Pharmacol. 2002, 441, 185-191. [CrossRef]

6. Shimoyama, M.; Tanaka, K.; Hasue, F.; Shimoyama, N. A mouse model of neuropathic cancer pain. Pain 2002, 99, 167-174. [CrossRef]

7. World Health Organization. Traitement de la Douleur Cancéreuse. Genève: Organisation Mondiale de la Santé. 1987. Available online: https:/ / apps.who.int/iris/handle/10665/41712 (accessed on 13 July 2020).

8. Mori, M.; Elsayem, A.; Reddy, S.K.; Bruera, E.; Fadul, N.A. Unrelieved pain and suffering in patients with advanced cancer. Am. J. Hosp. Palliat. Care 2012, 29, 236-240. [CrossRef]

9. Portenoy, R.K. Pharmacologic management of cancer pain. Semin. Oncol. 1995, 22, 112-120.

10. Khasabova, I.A.; Stucky, C.L.; Harding-Rose, C.; Eikmeier, L.; Beitz, A.J.; Coicou, L.G.; Hanson, A.E.; Simone, D.A.; Seybold, V.S. Chemical interactions between fibrosarcoma cancer cells and sensory neurons contribute to cancer pain. J. Neurosci. 2007, 27, 10289-10298. [CrossRef]

11. Das, A.; Pushparaj, C.; Bahí, N.; Sorolla, A.; Herreros, J.; Pamplona, R.; Vilella, R.; Matias-Guiu, X.; Martí, R.M.; Cantí, C. Functional expression of voltage-gated calcium channels in human melanoma. Pigment Cell Melanoma Res. 2012, 25, $200-212$. [CrossRef] [PubMed]

12. Nilius, B.; Wohlrab, W. Potassium channels and regulation of proliferation of human melanoma cells. J. Physiol. 1992, 445, 537-548. [CrossRef] [PubMed]

13. Lepple-Wienhues, A.; Berweck, S.; Böhmg, M.; Leo, C.P.; Meyling, B.; Garbe, C.; Wiederholt, M. K ${ }^{+}$Channels and the intracellular calcium signal in human melanoma cell proliferation. J. Membr. Biol. 1996, 151, 149-157. [CrossRef] [PubMed]

14. Berridge, M.J.; Bootman, M.D.; Roderick, H.L. Calcium signaling: Dynamics, homeostasis and remodeling. Nat. Rev. Mol. Cell Biol. 2003, 4, 517-529. [CrossRef] [PubMed]

15. Rao, V.R.; Perez-Neut, M.; Kaja, S.; Gentile, S. Voltage-gated ion channels in cancer cell proliferation. Cancers 2015, 7, 849-875. [CrossRef] [PubMed]

16. Warnier, M.; Roudbaraki, M.; Derouiche, S.; Delcourt, P.; Bokhobza, A.; Prevarskaya, N.; Mariot, P. CACNA2D2 promotes tumorigenesis by stimulating cell proliferation and angiogenesis. Oncogene 2015, 34, 5383-5394. [CrossRef] [PubMed]

17. Cheng, J.-K.; Chiou, L.-C. Mechanisms of the antinociceptive action of gabapentin. J. Pharmacol. Sci. 2006, 100, 471-486. [CrossRef]

18. Davies, A.; Douglas, L.; Hendrich, J.; Wratten, J.; Tran Van Minh, A.; Foucault, I.; Koch, D.; Pratt, W.S.; Saibil, H.R.; Dolphin, A.C. The calcium channel $\alpha_{2} \delta-2$ subunit partitions with Ca $\vee 2.1$ into lipid rafts in cerebellum: Implications for localization and function. J. Neurosci. 2006, 26, 8748-8757. [CrossRef] 
19. Dooley, D.J.; Taylor, C.P.; Donevan, S.; Feltner, D. $\mathrm{Ca}^{2+}$ channel alpha2delta ligands: Novel modulators of neurotransmission. Trends Pharmacol. Sci. 2007, 28, 75-82. [CrossRef]

20. Chincholkar, M. Analgesic mechanisms of gabapentinoids and effects in experimental pain models: A narrative review. Br. J. Anesth. 2018, 120, 1315-1334. [CrossRef]

21. Klugbauer, N.; Marais, E.; Hofmann, F. Calcium channel $\alpha 2 \delta$ subunits: Differential expression, function, and drug binding. J. Bioenrg. Biomembr. 2003, 35, 639-647. [CrossRef]

22. Martin, D.J.; McClelland, D.; Herd, M.B.; Sutton, K.G.; Hall, M.D.; Lee, K.; Pinnock, R.D.; Scott, R.H. Gabapentin-mediated inhibition of voltage-activated $\mathrm{Ca}^{2+}$ channel currents in culture sensory neurons is dependent on culture conditions and channel subunit expression. Neuropharmacology 2002, 42, 353-366. [CrossRef]

23. Brown, J.T.; Randall, A. Gabapentin fails to alter P/Q-type $\mathrm{Ca}^{2+}$ channel-mediated synaptic transmission in the hippocampus in vitro. Synapse 2005, 55, 262-269. [CrossRef] [PubMed]

24. Sills, G.J. The mechanisms of action of gabapentin and pregabalin. Curr. Opin. Pharmacol. 2006, 6, 108-113. [CrossRef] [PubMed]

25. Abbadie, C. Chemokines, chemokine receptors and pain. Trends Immunol. 2005, 26, 529-534. [CrossRef] [PubMed]

26. Zhang, J.; Patel, L.; Pienta, K.J. Targeting chemokine (C-C motif) ligand 2 (CCL2) as an example of translation of cancer molecular biology to clinic. Prog. Mol. Biol. Transl. Sci. 2010, 95, 31-53. [CrossRef] [PubMed]

27. Vergani, E.; Di Guardo, L.; Dugo, M.; Rigoletto, S.; Tragni, G.; Ruggieri, R.; Perrone, F.; Tamborini, E.; Gloghini, A.; Arienti, F.; et al. Overcoming melanoma resistance to vemurafenib by targeting CCL2-induced miR-34a, miR-100 and miR-125b. Oncotarget 2015, 7, 4428-4441. [CrossRef]

28. Van Steenwinckel, J.; Reaux-Le Goazigo, A.; Pommier, B.; Mauborgne, A.; Dansereau, M.-A.; Kitabgi, P.; Sarret, P.; Pohl, M.; Parsadaniantz, S.M. CCL2 Released from neuronal synaptic vesicles in the spinal cord is a major mediator of local inflammation and pain after peripheral nerve injury. J. Neurosci. 2011, 31, 5865-5875. [CrossRef] [PubMed]

29. Kwiatkowsky, K.; Popiolek-Barczyk, K.; Piotrowska, A.; Rojewska, E.; Clapala, K.; Makuch, W.; Mika, J. Chemokines CCL2 and CCL7, but not CCL12, play a significant role in the development of pain-related behavior and opioid-induced analgesia. Cytokine 2019, 119, 202-213. [CrossRef]

30. Torres-Mora, J.; Dry, S.; Li, X.; Binder, S.; Amin, M.; Folpe, A.L. Malignant melanotic schwannian tumor: A clinicopathologic, immunohistochemical, and gene expression profiling study of 40 cases, with a proposal for the reclassification of "melanotic schwannoma". Am. J. Surg. Pathol. 2014, 38, 94-105. [CrossRef]

31. Hart, I.R. The selection and characterization of an invasive variant of the B16 melanoma. Am. J. Pathol. 1979, 97, 587-600.

32. Pevida, M.; González-Rodríguez, S.; Lasta, A.; Hidalgo, A.; Menéndez, L.; Baamone, A. CCL2 release at tumor level contributes to the hiperalgesia evoked by intratibial inoculation of NCTC 2472 but not B16-F10 cells in mice. Naunyn-Schmiedeberg's Arch. Pharmacol. 2012, 385, 1053-1061. [CrossRef]

33. Umemura, M.; Baljinnyam, E.; Feske, S.; De Lorenzo, M.S.; Xie, L.-H.; Feng, X.; Oda, K.; Makino, A.; Fujita, T.; Yokoyama, U.; et al. Store-operated $\mathrm{Ca}^{2+}$ entry (SOCE) regulates melanoma proliferation and cell migration. PLoS ONE 2014, 9, e829292. [CrossRef] [PubMed]

34. Cox, J.L.; Lancaster, T.; Carlson, C.G. Changes in the motility of B16F10 melanoma cells induced by alterations in resting calcium influx. Melanoma Res. 2002, 12, 211-219. [CrossRef]

35. Deli, T.; Varga, N.; Adám, A.; Kenessey, I.; Rásó, E.; Puskás, L.G.; Tóvári, J.; Fodor, J.; Fehér, M.; Szigeti, G.P.; et al. Functional genomics of calcium channels in human melanoma cells. Int. J. Cancer 2007, 121, 55-65. [CrossRef]

36. Glass-Marmor, L.; Penso, J.; Beitner, R. Ca ${ }^{2+}$-induced changes in energy metabolism and viability of melanoma cells. Br. J. Cancer 1999, 81, 219-224. [CrossRef]

37. Croker, J.; Burmeister, B.; Foote, M. Neurotropic melanoma: The management of localised disease. J. Skin Cancer 2012, 2012, 706452. [CrossRef] [PubMed]

38. Mandybur, T.I. Melanotic nerve sheath tumors. J. Neurosurg. 1974, 4, 187-192. [CrossRef]

39. Honore, P.; Rogers, S.D.; Schwei, M.J.; Salak-Johnson, J.L.; Luger, N.M.; Sabino, M.C.; Clohisy, D.R.; Mantyh, P.W. Murine models of inflammatory, neuropathic and cancer pain each generates a unique set of neurochemical changes in the spinal cord and sensory neurons. Neuroscience 2000, 98, 585-598. [CrossRef]

40. Cain, D.M.; Wacnik, P.W.; Turner, M.; Wendelschafer-Crabb, G.; Kennedy, W.R.; Wilcox, G.L.; Simone, D.A. Functional interactions between tumor and peripheral nerve: Changes in excitability and morphology of primary afferent fibers in a murine model of cancer pain. J. Neurosci. 2001, 21, 9367-9376. [CrossRef]

41. Khasabov, S.G.; Hamamoto, D.T.; Harding-Rose, C.; Simone, D.A. Tumor-evoked hyperalgesia and sensitization of nociceptive dorsal horn neurons in a murine model of cancer pain. Brain Res. 2007, 1180, 7-19. [CrossRef]

42. Edwards, H.L.; Mulvey, M.R.; Bennett, M.I. Cancer-related neuropathic pain. Cancers 2019, 11, 373. [CrossRef] [PubMed]

43. Kuraishi, Y.; Iida, Y.; Zhang, H.-W.; Uehara, S.; Nojima, H.; Murata, J.; Saiki, I.; Takahata, H.; Ouchi, H. Suppression by gabapentin of pain-related mechano-responses in mice given orthotopic tumor inoculation. Biol. Pharm. Bull. 2003, 26, 550-552. [CrossRef]

44. Gustafsson, H.; Sandin, J. Oral pregabalin reverses cold allodynia in two distinct models of peripheral neuropathic pain. Eur. J. Pharmacol. 2009, 605, 103-108. [CrossRef]

45. Lindner, M.D.; Bourin, C.; Chen, P.; McElroy, J.F.; Leet, J.E.; Hogan, J.B.; Stock, D.A.; Machet, F. Adverse effects of gabapentin and lack of anti-allodynic efficacy of amitriptyline in the streptozotocin model of painful diabetic neuropathy. Exper. Clin. Psychopharmacol. 2006, 14, 42-51. [CrossRef] [PubMed] 
46. Mixcoatl-Zecuatl, T.; Quinonez-Bastidas, G.N.; Caram-Salas, N.L.; Ambriz-Tututi, M.; Araiza-Saldana, C.I.; Rocha-Gonzalez, H.I.; Medina-Santillan, R.; Reyes-Garcia, G.; Granados-Soto, V. Synergistic antiallodynic interaction between gabapentin or carbamazepine and either benfotiamine or cyanocobalamin in neuropathic rats. Methods Find Exp. Clin. Pharmacol. 2008, 30, 431-441. [CrossRef] [PubMed]

47. Taylor, C.P. The biology and pharmacology of calcium channel alpha2-delta proteins, Pfizer Satellite Symposium, 2003 Society for Neuroscience Meeting, Sheraton New Orleans Hotel, New Orleans, LA, EE.UU. 10 November 2003. CNS Drug Rev. 2004, 10, 183-188. [CrossRef] [PubMed]

48. Gee, N.S.; Brown, J.P.; Dissanayake, V.U.; Offord, J.; Thurlow, R.; Woodruff, G.N. The novel anticonvulsant drug, gabapentin (Neurontin), binds to the alpha2delta subunit of a calcium channel. J. Biol. Chem. 1996, 271, 5768-5776. [CrossRef] [PubMed]

49. Oka, M.; Itoh, Y.; Wada, M.; Yamamoto, A.; Fujita, T. Gabapentin blocks L-type and P/Q-type Ca ${ }^{2+}$ channels involved in oxide synthase activity in primary cultures of neurons from mouse cerebral cortex. Pharm. Res. 2003, 20, 897-899. [CrossRef] [PubMed]

50. Wang, M.; Offord, J.; Oxender, D.L.; Su, T.-Z. Structural requirement of the calcium-channel subunit $\alpha 2 \delta$ for gabapentin binding. Biochem. J. 1999, 342, 313-320. [CrossRef]

51. Fink, K.; Meder, W.; Dooley, D.J.; Göthert, M. Inhibition of neuronal Ca $\left({ }^{2+}\right)$ influx by gabapentin and subsequent reduction of neurotransmitter release from rat neocortical slices. Br. J. Pharmacol. 2000, 130, 900-906. [CrossRef]

52. Maneuf, Y.P.; McKnight, A.T. Block by gabapentin of the facilitation of glutamate release from rat trigeminal nucleus following activation of protein kinase C or adenylyl cyclase. Br. J. Pharmacol. 2001, 134, 237-240. [CrossRef]

53. Cunningham, M.O.; Woodhall, G.L.; Thompson, S.E.; Dooley, D.J.; Jones, R.S.G. Dual effects of gabapentin and pregabalin on glutamate release at rat entorhinal synapses in vitro. Eur. J. Neurosci. 2004, 20, 1566-1576. [CrossRef]

54. Maneuf, Y.P.; Hughes, J.; McKnight, A.T. Gabapentin inhibits the substance P-facilitated K(+)-evoked release of [(3)H]glutamate from rat caudial trigeminal nucleus slices. Pain 2001, 93, 191-196. [CrossRef]

55. Suárez, L.M.; Suárez, F.; Del Olmo, N.; Ruiz, M.; González-Escalada, J.R.; Solís, J.M. Presynaptic NMDA autoreceptors facilitate axon excitability: A new molecular target for the anticonvulsant gabapentin. Eur. J. Neurosci. 2005, 21, 197-209. [CrossRef]

56. Fink, K.; Dooley, D.J.; Meder, W.P.; Suman-Chauhan, N.; Duffy, S.; Clusmann, H.; Göthert, M. Inhibition of neuronal Ca ${ }^{2+}$ influx by gabapentin and pregabalin in the human neocortex. Neuropharmacology 2002, 42, 229-236. [CrossRef]

57. Taylor, C.P.; Angelotti, T.; Fauman, E. Pharmacology and mechanism of action of pregabalin: The calcium channel $\alpha 2-\delta$ (alpha2delta) subunit as a target for antiepileptic drug discovery. Epilepsy Res. 2007, 73, 137-150. [CrossRef] [PubMed]

58. Chen, J.; Li, L.; Chen, S.R.; Chen, H.; Xie, J.D.; Sirrieh, R.E.; MacLean, D.M.; Zhang, Y.; Zhou, M.H.; Jayaraman, V.; et al. The $\alpha 2 \delta$-1-NMDA Receptor Complex Is Critically Involved in Neuropathic Pain Development and Gabapentin Therapeutic Actions Cell Rep. 2018, 22, 2307-2321. [CrossRef] [PubMed]

59. Lee, H.J.; Wall, B.A.; Wangari-Talbot, J.; Shin, S.-S.; Rosenberg, S.; Chan, J.L.-K.; Namkoong, J.; Goydos, J.S.; Chen, S. Glutamatergic pathway targeting in melanoma: Single-agent and combinatorial therapies. Clin. Cancer Res. 2011, 17, 7080-7092. [CrossRef] [PubMed]

60. Martino, J.J.; Wall, B.A.; Mastrantoni, E.; Wilimczyk, B.J.; La Cava, S.N.; Degenhardt, K.; White, E.; Chen, S. Metabotropic glutamate receptor 1 (Grm1) is an oncogene in epithelial cells. Oncogene 2013, 32, 4366-4376. [CrossRef]

61. Namkoong, J.; Shin, S.-S.; Lee, H.J.; Marín, Y.E.; Wall, B.A.; Goydos, J.S.; Chen, S. Metabotropic glutamate receptor 1 and glutamate signaling in human melanoma. Cancer Res. 2007, 67, 2298-2305. [CrossRef]

62. Song, Z.; He, C.-D.; Liu, J.; Sun, C.; Lu, P.; Li, L.; Gao, L.; Zhang, Y.; Xu, Y.; Shan, L.; et al. Blocking glutamate-mediated signalling inhibits human melanoma growth and migration. Exp. Dermatol. 2012, 21, 926-931. [CrossRef]

63. Kuo, J.S.; Chen, S.F.; Huang, H.J.; Yang, C.S.; Tsai, P.J.; Hsueh, C.M. The involvement of glutamate in recall of the conditioned NK cell response. J. Neuroimmunol. 2001, 118, 245-255. [CrossRef]

64. Newton, R.A.; Bingham, S.; Case, P.C.; Sanger, G.J.; Lawson, S.N. Dorsal root ganglion neurons show increased expression of the calcium channel alpha2delta-1 subunit following partial sciatic nerve injury. Brain Res. Mol. Brain Res. 2001, 95, 1-8. [CrossRef]

65. Pan, H.L.; Eisenach, J.C.; Chen, S.R. Gabapentin suppresses ectopic nerve discharges and reverses allodynia in neuropathic rats. J. Pharmacol. Exp. Ther. 1999, 288, 1026-1030. [PubMed]

66. White, F.A.; Sun, J.; Waters, S.M.; Ma, C.; Ren, D.; Ripsch, M.; Steflik, J.; Cortright, D.N.; Lamotte, R.H.; Miller, R.J. Excitatory monocyte chemoattractant protein-1 signaling is up-regulated in sensory neurons after chronic compression of the dorsal root ganglion. Proc. Natl. Acad. Sci. USA 2005, 102, 14092-14097. [CrossRef] [PubMed]

67. Sun, J.H.; Yang, B.; Donnelly, D.F.; Ma, C.; LaMotte, R.H. MCP-1 enhances excitability of nociceptive neurons in chronically compressed dorsal root ganglia. J. Neurophysiol. 2006, 96, 2189-2199. [CrossRef] [PubMed]

68. Abbadie, C.; Lindia, J.A.; Cumiskey, A.M.; Peterson, L.B.; Mudgett, J.S.; Bayne, E.K.; DeMartino, J.A.; Macintyre, D.E.; Forrest, M.J. Impaired neuropathic pain responses in mice lacking the chemokine receptor CCR2. Proc. Natl. Acad. Sci. USA 2003, 100, 7947-7952. [CrossRef] [PubMed]

69. Richards, N.; Batty, T.; Dilley, A. CCL2 has similar excitatory effects to TNF- $\alpha$ in a subgroup of inflamed C-fiber axons. J. Neurophysiol. 2011, 106, 2838-2848. [CrossRef]

70. Golias, C.H.; Charalabopoulos, A.; Charalabopoulos, K. Cell proliferation and cell cycle control: A mini review. Int. J. Clin. Pract. 2004, 58, 1134-1141. [CrossRef] [PubMed]

71. Vermeulen, K.; Van Bockstaele, D.R.; Berneman, Z.N. The cell cycle: A review of regulation, deregulation and therapeutic targets in cancer. Cell Prolif. 2003, 36, 131-149. [CrossRef] 
72. Macià, A.; Herreros, J.; Martí, R.M.; Cantí, C. Calcium cannel expression applicability as a targeted therapies in melanoma. BioMed Res. Internat. 2015, 2015, 587135. [CrossRef]

73. Marciel, M.P.; Khadka, V.S.; Deng, Y.; Kilicaslan, P.; Pham, A.; Bertino, P.; Lee, K.; Chen, S.; Glibetic, N.; Hoffmann, F.W.; et al. Selenoprotein $\mathrm{K}$ deficiency inhibits melanoma by reducing calcium flux required for tumor growth and metastasis. Oncotarget 2018, 9, 13407-13422. [CrossRef] [PubMed]

74. Leary, S.; Underwood, W.; Anthony, R.; Cartner, S.; Grandin, T.; Greenacre, C.; Gwaltney-Brant, S.; McCrakin, M.A.; Meyer, R.; Miller, D.; et al. AVMA Guidelines for the Euthanasia of Animals: 2020 Edition; American Veterinary Medical Association: Schaumburg, IL, USA, 2020.

75. National-Research-Council of the National Academies. Guide for the Care and Use of Laboratory Animals, 8th ed.; The National Academies Press: Washington, DC, USA, 2011.

76. Atwal, N.; Casey, S.L.; Mitchell, V.A.; Vaughan, C.W. THC and gabapentin interactions in a mouse neuropathic pain model. Neuropharmacology 2019, 144, 115-121. [CrossRef] [PubMed]

77. Miranda, H.F.; Noriega, V.; Zepeda, R.; Zanetta, P.; Prieto-Rayo, J.; Prieto, J.C.; Sierralta, F. Antinociceptive synergism of gabapentin and nortriptyline in mice with partial sciatic nerve ligation. Pharmacology 2015, 95, 59-64. [CrossRef]

78. Meymandi, M.S.; Sepehri, G. Gabapentin action and interaction on the antinociceptive effect of morphine on visceral pain in mice. Eur. J. Anaesthesiol. 2008, 25, 129-134. [CrossRef]

79. Pavone, A.; Cardile, V. An in vitro study of new antiepileptic drugs and astrocytes. Epilepsia 2003, 44, 34-39. [CrossRef]

80. Jalalizadeh, H.; Souri, E.; Tehrani, M.B.; Jahangiri, A. Validated HPLC method for the determination of gabapentin in human plasma using pre-column derivatization with 1-fluoro-2,4-dinitrobenzene and its application to a pharmacokinetic study. J. Chromatogr. B Analyt. Technol. Biomed Life Sci. 2007, 854, 43-47. [CrossRef] [PubMed]

81. Baldewig, M.; Goldbaum, O.; Richter-Landsberg, C.; Weyland, A.; Bantel, C. Short-term incubation of gabapentin or pregabalin does not affect chemically induced injury in neuronal cell models in vitro. J. Pain Res. 2018, 11, 1181-1190. [CrossRef]

82. Mosmann, T. Rapid colorimetric assay for cellular growth and survival: Application to proliferation and cytotoxicity assays. J. Immunol. Methods 1983, 65, 55-63. [CrossRef]

83. Bolaños, P.; Guillén, A.; DiPolo, R.; Caputo, C. Factors affecting SOCE activation in mammalian skeletal muscle fibers. J. Phisiol. Sci. 2009, 59, 317-328. [CrossRef] [PubMed] 